\title{
Tropospheric ozone seasonal and long-term variability as seen by lidar and surface measurements at the JPL-Table Mountain Facility, California
}

\author{
Maria Jose Granados-Muñoz and Thierry Leblanc \\ Jet Propulsion Laboratory, California Institute of Technology, Wrightwood, CA, USA \\ Correspondence to: Maria Jose Granados-Muñoz (mamunoz@jpl.nasa.gov) \\ Received: 23 January 2016 - Published in Atmos. Chem. Phys. Discuss.: 23 February 2016 \\ Revised: 14 June 2016 - Accepted: 29 June 2016 - Published: 28 July 2016
}

\begin{abstract}
A combined surface and tropospheric ozone climatology and interannual variability study was performed for the first time using co-located ozone photometer measurements (2013-2015) and tropospheric ozone differential absorption lidar measurements (2000-2015) at the Jet Propulsion Laboratory Table Mountain Facility (TMF; elev. $2285 \mathrm{~m}$ ), in California.

The surface time series were investigated both in terms of seasonal and diurnal variability. The observed surface ozone is typical of high-elevation remote sites, with small amplitude of the seasonal and diurnal cycles, and high ozone values, compared to neighboring lower altitude stations representative of urban boundary layer conditions. The ozone mixing ratio ranges from $45 \mathrm{ppbv}$ in the winter morning hours to $65 \mathrm{ppbv}$ in the spring and summer afternoon hours. At the time of the lidar measurements (early night), the seasonal cycle observed at the surface is similar to that observed by lidar between 3.5 and $9 \mathrm{~km}$.

Above $9 \mathrm{~km}$, the local tropopause height variation with time and season impacts significantly the ozone lidar observations. The frequent tropopause folds found in the vicinity of TMF (27\% of the time, mostly in winter and spring) produce a dual-peak vertical structure in ozone within the fold layer, characterized by higher-than-average values in the bottom half of the fold (12-14 km), and lower-than-averaged values in the top half of the fold $(14-18 \mathrm{~km})$. This structure is consistent with the expected origin of the air parcels within the fold, i.e., mid-latitude stratospheric air folding down below the upper tropospheric sub-tropical air. The influence of the tropopause folds extends down to $5 \mathrm{~km}$, increasing the ozone content in the troposphere.
\end{abstract}

No significant signature of interannual variability could be observed on the 2000-2015 de-seasonalized lidar time series, with only a statistically non-significant positive anomaly during the years 2003-2007. Our trend analysis reveals however an overall statistically significant positive trend of 0.3 ppbv year $^{-1}(0.6 \%)$ in the free troposphere $(7-10 \mathrm{~km})$ for the period 2000-2015.

A classification of the air parcels sampled by lidar was made at $1 \mathrm{~km}$ intervals between 5 and $14 \mathrm{~km}$ altitude, using 12-day backward trajectories (HYSPLIT, Hybrid Single Particle Lagrangian Integrated Trajectory Model). Our classification revealed the influence of the Pacific Ocean, with air parcels of low ozone content (43-60 ppbv below $9 \mathrm{~km})$, and significant influence of the stratosphere leading to ozone values of $57-83 \mathrm{ppbv}$ down to $8-9 \mathrm{~km}$. In summer, enhanced ozone values ( $76 \mathrm{ppbv}$ at $9 \mathrm{~km})$ were found in air parcels originating from Central America, probably due to the enhanced thunderstorm activity during the North American Monsoon. Influence from Asia was observed throughout the year, with more frequent episodes during spring, associated with ozone values from 53 to $63 \mathrm{ppbv}$ at $9 \mathrm{~km}$.

\section{Introduction}

Ozone is an important constituent in the troposphere, impacting climate, chemistry and air quality (The Royal Society, 2008). As a greenhouse gas (Forster et al., 2007), it contributes to the Earth's global warming with an estimated radiative forcing of $0.40 \pm 0.20 \mathrm{~W} \mathrm{~m}^{-2}$ (IPCC, 2013). It is one of the main oxidants in the troposphere (Monks, 2005), 
and, in high concentrations, it can cause problems for human health and vegetation (World Health Organization, 2003). Tropospheric ozone is primarily formed as a secondary pollutant in chemical reactions involving ozone precursors such as methane, $\mathrm{CO}, \mathrm{NO}_{x}$, VOCs (volatile organic compounds) or PANs (peroxy acetyl nitrates). An additional source of ozone in the troposphere is the downward transport from the stratosphere, where ozone is much more abundant (Levy et al., 1985). At high elevation sites such as the Jet Propulsion Laboratory Table Mountain Facility in southern California (TMF hereafter), the effect of the boundary layer is very small, and ozone variability is expected to be driven by transport processes from the stratosphere or horizontal transport within the troposphere (Cui et al., 2009; Naja et al., 2003; Trickl et al., 2010).

Several studies show that background ozone levels have increased significantly since preindustrial times (Mickley et al., 2001; Parrish et al., 2012; Staehelin et al., 1994; Volz and Kley, 1988) and these levels continued rising in the last decades in both Hemispheres (Derwent et al., 2007; Jaffe et al., 2004; Lee et al., 1998; Naja and Akimoto, 2004; Oltmans et al., 2006; Parrish et al., 2012; Simmonds et al., 2004; Tanimoto et al., 2009; Zbinden et al., 2006; Lelieveld et al., 2004). Nevertheless, after air quality regulations were implemented in the 1970s, the increasing trend has slowed down or even reversed in regions such as the eastern USA and Europe (Cooper et al., 2012, 2014; Granier et al., 2011). The situation is not the same for emerging economies such as Asia, where emissions are increasing with a corresponding increase in ozone levels (Dufour et al., 2010; Gao et al., 2005; Strode et al., 2015; Tie et al., 2009; Wang et al., 2006).

In most cases, variability and trend studies have revealed very large ozone variability with time, location and altitude (Cooper et al., 2014). This variability is mostly due to the large heterogeneity and variability of the ozone sources themselves, the different chemical processes affecting the formation and depletion of tropospheric ozone and its variable lifetime in the troposphere. Ozone atmospheric lifetime goes from a few hours in the polluted boundary layer to several weeks in the free troposphere, allowing it to travel over distances of intercontinental scale (Stevenson et al., 2006; Young et al., 2013). Additional factors that have been observed to influence tropospheric ozone variability are climate variability and related global circulation patterns such as ENSO (El Niño-Southern Oscillation) or PDO (Pacific Decadal Oscillation) (e.g., Lin et al., 2014, 2015a; Neu et al., 2014). Tropopause folds also play a key role on tropospheric ozone interannual variability, as they influence the ozone budget in the troposphere and can even affect air quality near the surface (e.g., Lin et al., 2015a; Brown-Steiner and Hess, 2011; Langford et al., 2012). In order to obtain statistically significant results and be able to assess tropospheric ozone interannual variability and trends, a large long-term monitoring data set with global coverage is required. In the last decades, efforts have been made in this respect and the number of tropospheric ozone measurements has considerably increased throughout the globe. However, it is still necessary to increase the current observation capabilities to characterize tropospheric ozone variability more accurately.

Long-term records of tropospheric ozone have been available since the 1950s (Feister and Warmbt, 1987; Parrish et al., 2012), but it is not until the 1970s that the number of ozone monitoring stations became significant (Cooper et al., 2014 and references therein). Currently, a considerable number of ozone monitoring sites are operating as part of regional networks or international programs (e.g., World Meteorological Observation Global Atmosphere Watch WMO/GAW, Acid Deposition Monitoring Network in East Asia EANET, Clean Air Status and Trends Network CASTNET). In addition to these ground-based networks, tropospheric ozone measurements from satellite (TOMS, TES, OMI, etc.) or aircraft (MOZAIC/IAGOS) platforms have been successfully implemented. Nevertheless, a large fraction of the tropospheric ozone measurements are still only surface or columnintegrated measurements whilst the number of them with information on the vertical coordinate is very small. Until recently, mainly ozonesonde profiles have been used to provide altitude-resolved ozone variability information in the troposphere (Logan, 1994; Logan et al., 1999; Naja and Akimoto, 2004; Oltmans et al., 1998, 2006, 2013; Newchurch et al., 2003), but the cost of an ozonesonde launch has kept the sampling interval to one profile per week (or less) for a given location. Ozone vertical profiles have also been obtained from aircraft platforms through programs such as MOZAIC and IAGOS, available since 1995 (e.g., Zbinden et al., 2013; Logan et al., 2012). However, aircraft data are limited to air traffic routes and the temporal resolution depends on the frequency of the commercial flights. Differential absorption lidar (DIAL) systems, which started to be used to measure tropospheric ozone in the late 1970s (Bufton et al., 1979; Proffit and Langford, 1997), complement the ozonesonde and aircraft records, providing higher temporal resolution thanks to their inherent operational configuration (from minutes to days of continuous measurements). Currently, tropospheric ozone lidars are still very scarce, but the implementation of observation networks such as the international Network for the Detection of Atmospheric Composition Change (NDACC; http://www.ndsc.ncep.noaa.gov), and more recently the North American-based Tropospheric Ozone Lidar Network (TOLNet; http://www-air.larc.nasa. gov/missions/TOLNet) allows for new capabilities that can contribute to the understanding of processes affecting tropospheric ozone variability, and to satellite and model validation and improvement.

As part of NDACC and TOLNet, a tropospheric ozone DIAL system located at TMF has been operating since 1999. In this study, an analysis of 16 years of lidar profiles measured at the station is presented together with the analysis of the surface ozone measurements that have been available at the site since 2013. The objective is to provide the first- 
ever published study of tropospheric ozone variability above TMF using both the surface and lidar data sets. The work presented here is particularly valuable due to the rising interest in the detection of long-term trends in the western USA and the scarcity of long-term measurements of ozone vertical profiles in this region. The high-terrain elevation and the deep planetary boundary layer of the intermountain western USA region facilitate inflow of polluted air masses originating in the Asian boundary layer and ozone-rich stratospheric air down to the surface, thus highly influencing air quality in the region (Brown-Steiner and Hess, 2011; Cooper et al., 2004; Langford et al., 2012; Liang et al., 2004; Lin et al., 2012a, b; Stohl, 2002). After a brief description of the instrumentation and data sets (Sect. 2), an analysis of the seasonal and interannual variability of tropospheric ozone above TMF for the period 2000-2015 will be presented in Sect. 3. The study includes a characterization of the air parcels sampled by lidar by identification of the source regions based on backward trajectories analysis. Concluding remarks are provided in Sect. 4.

\section{Instrumentation}

\subsection{Tropospheric ozone lidar}

TMF is located in the San Gabriel Mountains, in southern California $\left(34.4^{\circ} \mathrm{N}, 117.7^{\circ} \mathrm{W}\right)$, at an elevation of $2285 \mathrm{~m}$ above sea level. Two DIAL and one Raman lidar have been operating at the facility during nighttime typically 4 times per week, $2 \mathrm{~h}$ per night, contributing stratospheric ozone, temperature, tropospheric ozone, and water vapor measurements to NDACC for several decades now. The original design in the mid-1990s of the tropospheric ozone DIAL was optimized for tropospheric ozone and aerosol measurements (McDermid, 1991). The system was later re-designed to provide exclusively tropospheric ozone profiles (McDermid et al., 2002). The emitter uses a quadrupled Nd:YAG laser emitting two beams at $266 \mathrm{~nm}$. One beam passes through a Raman cell filled with Deuterium to shift the wavelength to $289 \mathrm{~nm}$, the other beam passes through another cell filled with Hydrogen to shift the wavelength to $299 \mathrm{~nm}$. The two beams are then expanded 5 times and transmitted into the atmosphere. The light elastically backscattered in the troposphere $(3-20 \mathrm{~km})$ is collected by three (later five) telescopes comprising mirrors of diameters varying from $91 \mathrm{~cm}$ diameter to $5 \mathrm{~cm}$ diameter, thus accommodating for the large signal dynamic range occurring when collecting light from this close range. A total of three pairs of 289/299 nm channels is thus used to retrieve ozone using the DIAL technique, each pair corresponding to a different intensity range, and the retrieved ozone profiles from all pairs combined ultimately cover the entire troposphere $(3-18 \mathrm{~km})$. As part of the retrieval process, the upper range of the ozone profile is further extended to about $25 \mathrm{~km}$ by applying the DIAL technique on the $299 \mathrm{~nm}$ high inten- sity channel of the tropospheric ozone lidar and the $355 \mathrm{~nm}$ low-intensity channel of the co-located water vapor Raman lidar (Leblanc et al., 2012).

The instrument temporal sampling can be set to any value from a few seconds to several hours and the vertical sampling can be set to any multiple of $7.5 \mathrm{~m}$, depending on the science or validation need. For the routine measurements contributing to NDACC over the period 1999-2015 and used for the present work, the standard settings have typically ranged between 5 and $20 \mathrm{~min}$ for temporal sampling, and between 7.5 and $75 \mathrm{~m}$ for the vertical sampling. Profiles routinely archived at NDACC are averaged over $2 \mathrm{~h}$, with an effective vertical resolution varying from $150 \mathrm{~m}$ to $3 \mathrm{~km}$, decreasing with altitude. These temporal and vertical resolution settings yield a standard uncertainty of 7-14\% throughout the profile. The system operates routinely at nighttime, but daytime measurements with reduced signal-to-noise ratio are occasionally performed in special circumstances such as process studies, and aircraft or satellite validation. The total number of routine $2 \mathrm{~h}$ ozone profiles used in this study and archived at NDACC for the period 2000-2015 is included in Table 1.

The TMF ozone lidar measurements have been regularly validated using simultaneous and co-located electrochemical concentration cell (ECC) sonde measurements (Komhyr, 1969; Smit et al., 2007). In the troposphere the precision of the ozonesonde measurement is approximately $3-5 \%$ with accuracy of $5-10 \%$ below $30 \mathrm{~km}$. TMF has had ozonesonde launch capability since 2005 and 32 coincident profiles were obtained over the period 2005-2013. Results from the lidar and the ECC comparison are included in Fig. 1. Figure 1a shows the averaged relative difference between the lidar and ECC ozone number density profiles for the 32 cases. The lidar and sonde measurements are found to be in good agreement, with an average difference of $7 \%$ in the bulk of the troposphere and most of the values under $10 \%$ (Fig. 1b), which is within the combined uncertainty computed from both the lidar and sonde measurements. Note that a non-negligible fraction of the differences is due to the different measurement geometry of the lidar and ozonesonde: $2 \mathrm{~h}$ averaged, single location for lidar, and horizontally drifting $1 \mathrm{sec}$ measurements for the ozonesonde usually rising at $5 \mathrm{~m} \mathrm{~s}^{-1}$. Figure $1 \mathrm{c}$ reveals that the deviations do not present significant changes with time, which is an indicator of the system stability despite the multiple upgrades made over this time period.

\subsection{Surface ozone measurements}

Continuous surface ozone measurements have been performed at TMF since 2013 using the UV (ultraviolet) photometry technique (Huntzicker and Johnson, 1979) with a UV photometric ozone analyzer (Model 49i from Thermo Fisher Scientific, US). The operation principle is based on the absorption of UV light at $254 \mathrm{~nm}$ by the ozone molecules (Sinha et al., 2014). The instrument collects in situ air samples at $2 \mathrm{~m}$ above ground taken from an undisturbed forested 
Table 1. Number of measurements, by month and years, performed at TMF with the tropospheric ozone DIAL system. NA indicates data not available at the time of the study.

\begin{tabular}{rrrrrrrrrrrrr|r}
\hline & Jan & Feb & Mar & Apr & May & Jun & Jul & Aug & Sep & Oct & Nov & Dec & Total \\
\hline 2000 & 4 & 2 & 6 & 4 & 11 & 12 & 7 & 10 & 8 & 1 & 0 & 0 & 65 \\
2001 & 1 & 11 & 17 & 2 & 9 & 13 & 12 & 15 & 15 & 17 & 8 & 10 & 130 \\
2002 & 6 & 10 & 6 & 4 & 0 & 10 & 11 & 1 & 6 & 16 & 12 & 11 & 93 \\
2003 & 11 & 9 & 15 & 12 & 10 & 13 & 5 & 7 & 9 & 14 & 7 & 5 & 117 \\
2004 & 9 & 8 & 15 & 14 & 12 & 6 & 12 & 13 & 11 & 10 & 9 & 11 & 130 \\
2005 & 4 & 6 & 13 & 8 & 12 & 16 & 9 & 2 & 7 & 2 & 11 & 9 & 99 \\
2006 & 11 & 9 & 6 & 8 & 14 & 5 & 2 & 12 & 12 & 20 & 6 & 1 & 106 \\
2007 & 0 & 0 & 4 & 9 & 11 & 7 & 8 & 10 & 8 & 26 & 10 & 8 & 101 \\
2008 & 7 & 11 & 8 & 13 & 9 & 4 & 11 & 10 & 6 & 11 & 4 & 6 & 100 \\
2009 & 14 & 11 & 7 & 5 & 7 & 8 & 4 & 10 & 4 & 17 & 1 & 3 & 91 \\
2010 & 0 & 0 & 3 & 8 & 0 & 7 & 4 & 1 & 4 & 5 & 9 & 3 & 44 \\
2011 & 2 & 6 & 4 & 7 & 7 & 11 & 10 & 12 & 7 & 8 & 8 & 8 & 90 \\
2012 & 0 & 9 & 9 & 1 & 10 & 13 & 3 & 2 & 5 & 8 & 4 & 5 & 69 \\
2013 & 6 & 3 & 5 & 10 & 8 & 7 & 5 & 7 & 0 & 0 & 0 & 0 & 51 \\
2014 & 9 & 2 & 5 & 10 & 13 & 16 & 15 & 11 & 15 & 15 & 14 & 6 & 131 \\
2015 & 9 & 15 & 12 & 18 & 3 & 14 & 12 & NA & NA & NA & NA & NA & 83 \\
\hline Total & 93 & 112 & 135 & 133 & 136 & 162 & 130 & 123 & 117 & 170 & 103 & 86 & 1500 \\
\hline
\end{tabular}

(a)

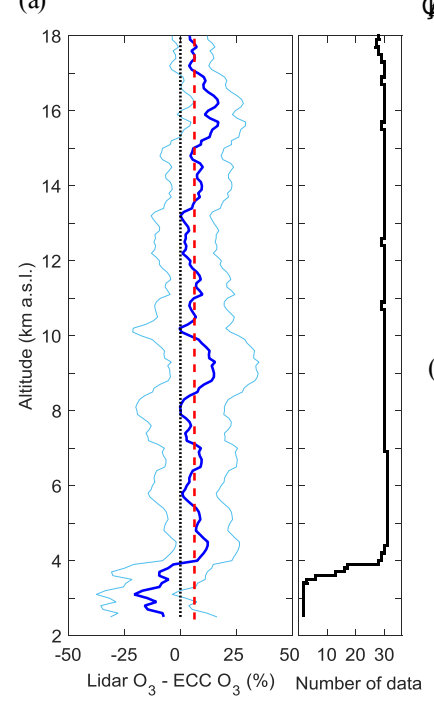

b)

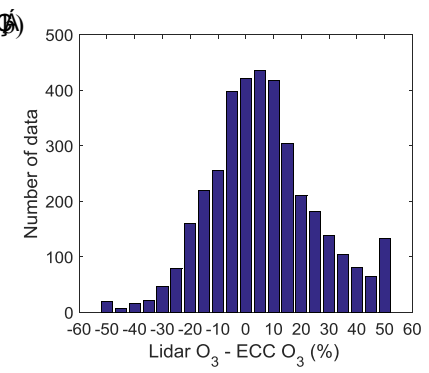

(c)

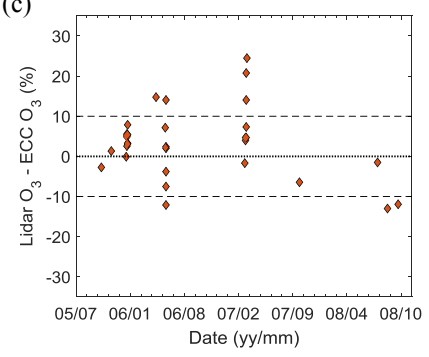

Figure 1. (a) Profile of the mean relative difference between the lidar and the ECC ozone number density for the 32 simultaneous measurements (dark blue). Lidar uncertainty (light blue) and mean relative difference obtained between 4 and $16 \mathrm{~km}$ (red dotted line) are superimposed. The black solid curve shows the number of data points at each altitude. (b) Histogram of the difference between the lidar and the ECC ozone number density. (c) Column-averaged (below $8 \mathrm{~km}$ ) difference between the lidar and the ECC sonde for each coincidence.

environment adjacent to the lidar building. It provides ozone mixing ratio values at 1 min time intervals with a lower detection limit of 1 ppbv. Uncertainty has been reported to be below $6 \%$ in previous studies (Sinha et al., 2014).

\section{Results}

\subsection{Surface ozone variability}

Figure 2a shows the surface ozone seasonal cycle at TMF and nearby stations from the California Air Resources Board (ARB) air quality network for the period 20132015. The seasonal cycle at TMF comprises a maximum in spring and summer and a minimum in winter, consistent with the ARB stations shown, as well as other stations in the US west coast (e.g., Schnell et al., 2015). Nonetheless, the seasonal cycle obtained at TMF from the hourly samples (left plot) presents larger ozone values and lower variability throughout the year compared to the other ARB stations, all of which are at lower altitudes. The mean surface value for the complete period at TMF is $55 \mathrm{ppbv}$, whereas the seasonal values are 57, 57, 52 and 45 ppbv in spring (March-April-May), summer (June-JulyAugust), fall (September-October-November) and winter (December-January-February), respectively. These values are in good agreement with those obtained from surface measurements at high elevation sites in the Northern Hemisphere and reported in the review by Cooper et al. (2014). When using the $8 \mathrm{hMDA}$ ( $8 \mathrm{~h}$ maximum daily average; right plot), larger seasonal-cycle amplitudes occur, especially at stations affected by anthropogenic pollution such as Crestline or San Bernardino. These polluted stations present larger values in summer than those recorded at high-elevation remote stations like Joshua Tree or TMF. The mean 8hMDA at TMF is $58 \mathrm{ppbv}$ and the seasonal averages are 62, 66, 57 and 49 for spring, summer, fall and winter, respectively. The observed low seasonal variability is typical of high-elevation remote sites with low urban influence (Brodin et al., 2010). 

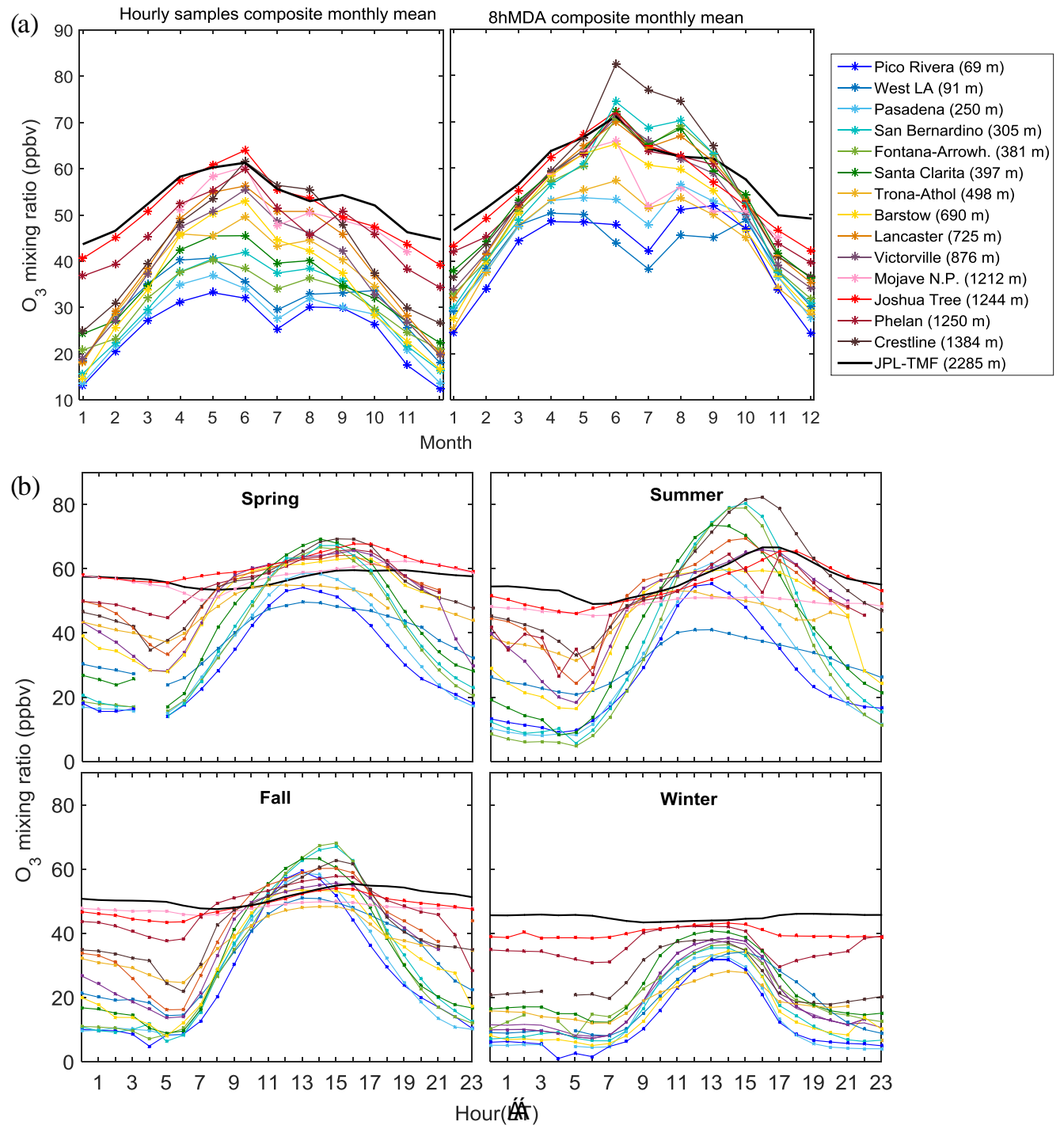

Figure 2. (a) Composite monthly mean surface ozone at TMF and nearby ARB stations obtained from hourly samples (left) and 8hMDA values (right) for the period 2013-2015. (b) Composite mean ozone daily cycle at TMF and nearby ARB stations for the four seasons for the period 2013-2015.

A similar behavior can be observed at the Phelan, Joshua Tree or the Mojave National Preserve stations, all sites being at high elevation with low or negligible urban influence. In Fig. 2a a secondary minimum is observed at TMF and most of the ARB nearby stations in July-August, followed by a secondary maximum in fall.

In Fig. 2a a clear combined effect of the altitude and proximity to anthropogenic pollution sources on the ozone levels is observed. In general, higher ozone levels and lower variability are observed at higher altitudes. The lowest altitude Pico Rivera instrument measures the lowest ozone levels, and the highest-altitude TMF instrument measures the highest ozone levels throughout the year when considering the hourly sampled data set. A mean difference of $\sim 30 \mathrm{ppbv}$ is observed for a $2 \mathrm{~km}$ altitude difference. The magnitude of this positive ozone vertical gradient depends on the distance from anthropogenic pollution sources. The effect of pollution is clearer on the 8hMDA data, where high-elevation stations, yet more likely to be affected by pollution such as Crestline or Victorville, present a larger seasonal-cycle amplitude associated with lower ozone levels in winter and higher levels in summer. A similar impact of the interplay between urban influence and high-elevation was previously reported by Brodin et al. (2010).

The difference between the seasonal cycle retrieved from the $1 \mathrm{~h}$ averaged data and the 8hMDA can be easily explained from the differences in the daily cycles at the different stations. The mean surface ozone diurnal cycle at TMF and nearby ARB stations is shown in Fig. $2 b$ for the four seasons. Minimum values are observed at nighttime, whereas max- 
ima appear in late afternoon. As for the seasonal cycle, the daily cycle at TMF, Joshua Tree, Mojave National Preserve and Phelan stations exhibit low variability compared to the other stations located at lower altitude and more affected by urban pollution. On average, daily values are larger at highelevation remote sites such as TMF or Joshua Tree. However, the afternoon maximum is larger at polluted stations such as Crestline, especially in the summer season. In addition, the maximum at TMF and the ARB stations of Joshua Tree and Mojave National Preserve occurs later than at the other stations. The difference in timing is likely due to the different chemical species involved in the ozone formation and depletion processes due to the low influence of anthropogenic pollution (Brodin et al., 2010; Gallardo et al., 2000; Naja et al., 2003). In winter, a minimum is observed at TMF in the afternoon instead of the maximum observed at the other stations. This difference in diurnal pattern has been observed at other remote or high-elevation sites and has been attributed to the shorter day length and the lack of ozone precursors compared to urban sites. The resulting daytime photochemical ozone formation is insufficient to produce an ozone diurnal variation maximizing in the afternoon (Brodin et al., 2010; Gallardo et al., 2000; Naja et al., 2003; Oltmans and Komhyr, 1986; Pochanart et al., 1999; Tsutsumi and Matsueda, 2000).

\subsection{Tropospheric ozone variability}

The red curve in Fig. 3a (left plot) shows the average ozone profile in the troposphere and the UTLS (upper tropospherelower stratosphere) region obtained by the TMF lidar for the period 2000-2015. The cyan horizontal bars show the corresponding standard deviation at $\sim 1 \mathrm{~km}$ interval. The red dot at the bottom of the profile shows the 2013-2015 mean surface ozone obtained from the data acquired simultaneously to the lidar measurements. The lidar system provides information from approximately $1.3 \mathrm{~km}$ (from $200 \mathrm{~m}$ since 2013) above the surface up to $25 \mathrm{~km}$, covering the whole troposphere and the lower stratosphere. The average mixing ratio value in the mid-troposphere is $55 \mathrm{ppbv}$. Above $8 \mathrm{~km}$, the ozone mixing ratio increases, reaching values above $1000 \mathrm{ppbv}$ at $16 \mathrm{~km}$.

The seasonally averaged profiles are shown in Fig. 3b. These averages represent larger values in spring and summer in the troposphere, whereas in the stratosphere maximum values occur in winter and spring. Within the troposphere, below $9 \mathrm{~km}$, the seasonally averaged profiles show average values of $62,60,51$ and $50 \mathrm{ppbv}$ in spring, summer, fall and winter, respectively. These values are in good agreement with the average ozone concentrations (50-70 ppbv) obtained in previous studies (Thompson et al., 2007; Zhang et al., 2010) above the western USA. In the altitude range 9-16 km (UTLS) a much larger variability in ozone is observed, as indicated by the large standard deviation (left plot) and the differences between the seasonally averaged profiles (right plot). This large variability results from the horizontal and vertical displace- (a)

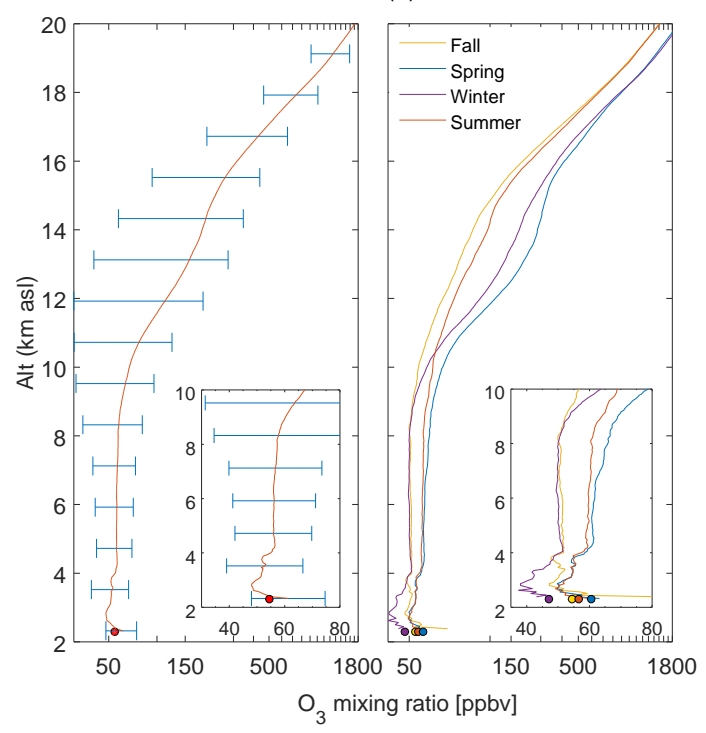

Figure 3. (a) Ozone mixing ratio climatological average (20002015) computed from the TMF lidar measurements (red curve). The cyan horizontal bars indicate the standard deviation at intervals of $1 \mathrm{~km}$. The red dot at the bottom indicates the mean surface ozone mixing ratio (2013-2015) measured simultaneously with lidar. A zoomed version of the plot focused on the tropospheric part of the profiles $(2-10 \mathrm{~km})$ is inserted within the figure. (b) Seasonally averaged ozone mixing ratio profiles for spring (MAM), summer (JJA), fall (SON) and winter (DJF). The dots at the bottom indicate the corresponding surface ozone seasonal averages. A zoomed version of the plot focused on the tropospheric part of the profiles $(2-10 \mathrm{~km})$ is inserted within the figure.

ment of the tropopause above the site, causing the lidar to sound either the ozone-rich lowermost stratosphere or the ozone-poor sub-tropical upper troposphere for a given altitude.

The two-dimensional (2-D) color contours of Fig. 4 show the composite (2000-2015) monthly mean ozone climatology measured by lidar (main panel, 4-20 km). A similar 2-D color contour representation was used just below the main panel to represent the composite (2013-2015) monthly mean surface ozone. The climatological tropopause height at TMF is also included in the main panel (blue dotted line), with mean values ranging between 12 and $15 \mathrm{~km}$. As discussed previously in this paper, the tropopause height variability is the main cause of the larger standard deviation observed in Fig. $3 \mathrm{a}$ in this region. Between the surface and $9 \mathrm{~km}$, a very consistent seasonal pattern occurs, with maximum values in April-May and minimum values in winter. The springsummer maximum in the free-troposphere has been consistently observed at other stations in Europe and North America and is commonly attributed to photochemical production (Law et al., 2000; Petetin et al., 2015; Zbinden et al., 2006). The maximum values in the western USA are also usually 


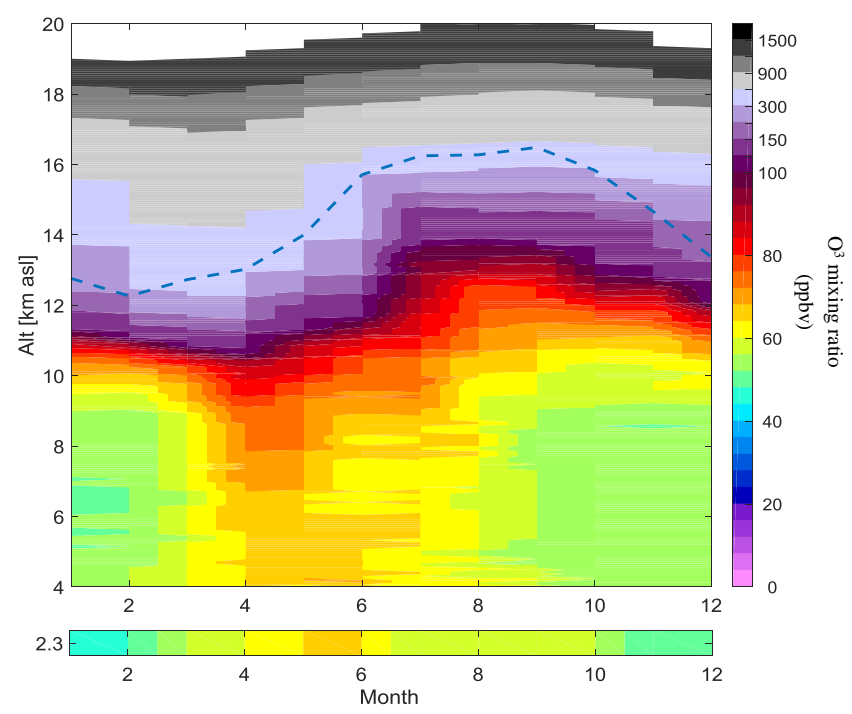

Figure 4. Composite monthly mean ozone mixing ratio (20002015) computed from the TMF lidar measurements. The dashed line indicates the climatological tropopause above the site (WMO definition). Bottom strip: composite monthly mean ozone mixing ratio (2000-2015) from the surface measurements.

related to the influence of Asian emissions reaching the US west coast (Jaffe et al., 2003; Parrish et al., 2004; Cooper et al., 2005b; Neuman et al., 2012; Zbinden et al., 2013). Above $9 \mathrm{~km}$, the seasonal maximum occurs earlier (i.e., in March and April between 10 and $12 \mathrm{~km}$ and February and March at higher altitudes) consistent with the transition towards a dynamically driven lower-stratospheric regime. At these altitudes, the ozone minimum is also displaced earlier in the year (August-October), which is consistent with the findings of Rao et al. (2003) above Europe.

The TMF surface and lidar data are found to be very consistent, both in terms of seasonal-cycle phase and amplitude, and in term of absolute mixing ratio values. The mean value obtained from the lidar measurements in the troposphere is very similar to the mean value obtained from the surface measurements (around $55 \mathrm{ppbv}$ ). This consistency points out that the TMF surface measurements are representative of the lower part of the free troposphere (i.e., below $7 \mathrm{~km}$ ), at least during the nighttime lidar measurements. This is mostly due to the fact that the station is not affected by the boundary layer during most of the time because of its high-elevation. Additional daytime lidar measurements will be performed in 2016 to assess whether such consistency also exists at other times of the day, especially in the afternoon.

\subsection{Interannual variability and trends}

The 2000-2015 time series of the de-seasonalized ozone mixing ratio is shown in Fig. 5. Anomalies, expressed in percent, resulted from subtracting the climatological ozone monthly mean profiles computed for the period 2000-2015 to the measured lidar profiles. Large ozone variability with time is clearly observed, highlighting the difficulty in identifying trends and patterns. No clear mode of interannual variability is observed for the analyzed period here. However, positive anomalies seem to predominate throughout the troposphere during the period 2003-2007, especially below $7 \mathrm{~km}$. On average, ozone mixing ratio values in the lower troposphere were 5 ppbv larger in 2003-2007 than during the entire period 2000-2015.

Following a procedure similar to that described in Cooper et al. (2012), a trend analysis was performed at different altitude levels (Tables 2 and 3 and Fig. 6). Figure 6 shows the time series of the median, 95th and 5th percentile values, obtained every year between 2000 and 2015 for different layers and different seasons using the lidar profiles measured at TMF. In order to obtain the trends, linear fits (shown in Fig. 6) of the median, 95th and 5th percentiles were performed independently using the least squares method. The ozone rate of change in ppbv year ${ }^{-1}$ was determined from the slope of the linear fit. To assess the significance of the trends, the $F$ statistic test was used, with the $p$ value as an indicator of the statistical significance. $P$ values lower than 0.05 (0.10), indicate statistically significant trends, with a confidence level larger than $95 \%$ (90\%).

The calculated trends depend on altitude and season. Table 2 contains the ozone rate change expressed in ppbv year $^{-1}$ (and \% year ${ }^{-1}$ ) for the different layers and seasons for the median, 5th and 95th percentiles. The corresponding standard errors and $p$ values are included in Table 3. Statistically significant trends at 95 and $90 \%$ confidence levels are marked in bold and italic font respectively. The layer corresponding to the upper troposphere $(7-10 \mathrm{~km})$ shows a statistically significant ozone increase of $0.31 \pm 0.15 \mathrm{ppbv}$ year $^{-1}\left(0.57 \pm 0.28 \%\right.$ year $^{-1}$, $p=0.06$ ) for the median values and $0.55 \pm 0.30 \mathrm{ppbv}$ year $^{-1}$ $\left(0.54 \pm 0.29 \%\right.$ year $\left.^{-1}, p=0.09\right)$ for the 95 th percentile, indicating that both the background and the high intensity ozone events levels were increasing (Cooper et al., 2012, 2014). Cooper et al. (2012) reported a similar increase in the free troposphere and in the western USA for the period 1990-2010 for both the median and 95th percentiles.

Analyzing each season separately, a significant positive trend occurs in the upper troposphere $(7-10 \mathrm{~km})$ for both spring and summer, with an ozone increasing

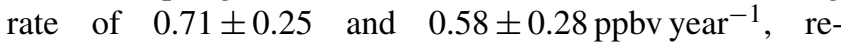
spectively (or $1.10 \pm 0.39 \%$ and $0.98 \pm 0.47 \%$ year $^{-1}$, $p=0.01$ and $p=0.05$ ), and an ozone decrease of $-0.43 \pm 0.18$ ppbv year $^{-1} \quad\left(-0.87 \pm 0.34 \%\right.$ year $^{-1}$, $p=0.03$ ) during winter. Statistically significant negative trends were also found in the lower troposphere $(4-7 \mathrm{~km})$ during winter for the median and 5th percentile values with an ozone decrease of $-0.36 \pm 0.16$ and $-0.59 \pm 0.18$ ppbv year $^{-1}$, respectively $\quad\left(-0.72 \pm 0.32 \%\right.$ year $^{-1}, \quad p=0.04, \quad$ and $-1.53 \pm 0.47 \%$ year $^{-1}, \quad p=0.0004$, respectively) $\quad(\mathrm{Ta}-$ 


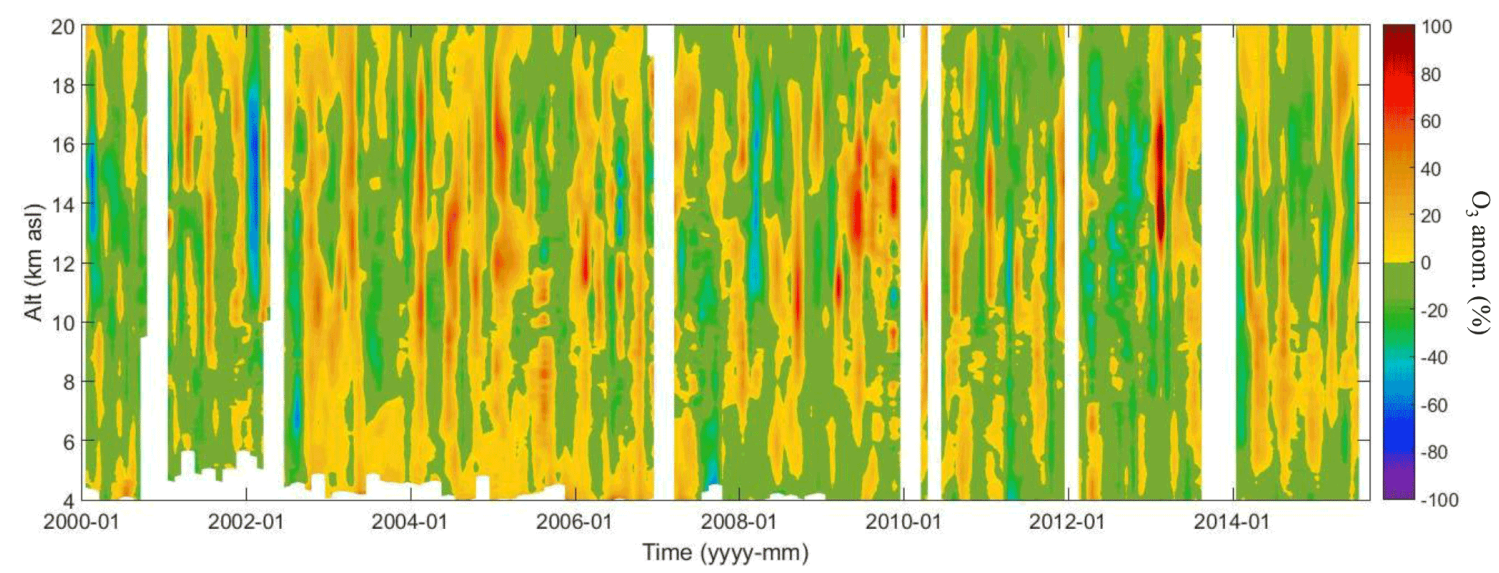

Figure 5. De-seasonalized ozone mixing ratio above TMF. Anomalies (in \%) were computed with respect to the climatological (2000-2015) monthly means.
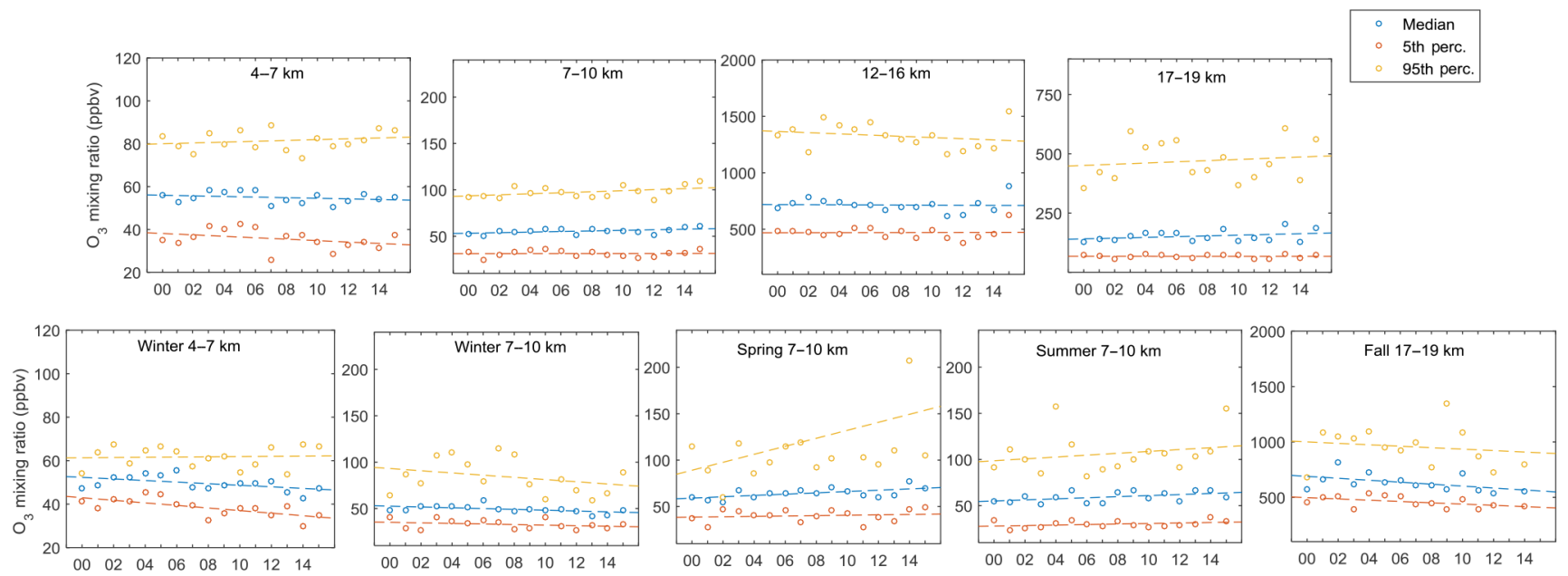

Figure 6. Time series of the median (blue), 5th (orange) and 95th (yellow) percentile ozone values at different altitude layers for the full year (top) and for selected seasons and altitude layers (bottom) obtained from the TMF lidar measurements. Dashed lines represent the linear fit for each time series.

ble 2). Trends near the tropopause $(12-16 \mathrm{~km})$ are not significant, whereas a significant negative trend of $\quad-8.8 \pm 4.5$ ppbv year $^{-1} \quad\left(-1.39 \pm 0.71 \%\right.$ year $^{-1}$, $p=0.07)$ for the median and $-5.8 \pm 2.9$ ppbv year $^{-1}$ $\left(-1.26 \pm 0.63 \%\right.$ year $\left.^{-1}, p=0.07\right)$ for the 5 th percentile in fall occurred in the lower stratosphere $(17-19 \mathrm{~km})$.

The positive trend at TMF in spring for the median values is larger than the trend obtained by Cooper et al. (2012) for the free troposphere in 1995-2011 $\left(0.41 \pm 0.27\right.$ ppbv year $\left.^{-1}\right)$, and even larger than the trend obtained by Lin et al. (2015b) using model data $\left(0.36 \pm 0.18\right.$ ppbv year $^{-1}$ during $\left.1995-2014\right)$. This disagreement could be due to differences in sampling, as concluded in Lin et al. (2015b). Nonetheless, Fig. 6 shows larger ozone median (and 5th and 95th percentile) values at $7-10 \mathrm{~km}$ in 2013-2015 than in preceding years. A lower ozone increas- ing rate in 2000-2012 above TMF (0.56 ppbv year $\left.{ }^{-1}\right)$ suggests that the ozone rate of change has increased in the last years, but a more comprehensive study with regional coverage would be necessary to confirm the significance of this change. Regarding winter season, a positive trend was obtained on a regional scale in Cooper et al. (2012), but certain sites in the western USA showed a negative trend, even though not statistically significant. Analyzing the period 2000-2010 as in Cooper et al. (2012), we still observe a negative trend at TMF $\left(-0.07\right.$ ppbv year $\left.^{-1}\right)$, but it is not statistically significant for this shorter period ( $p=0.83$ ).

The springtime positive trend estimates reported in the western USA oppose ozone decrease in the eastern part. These results indicate that the 2-decade-long efforts to implement regulations to control air quality and anthropogenic emissions in the USA have led to a clear decrease in ozone 


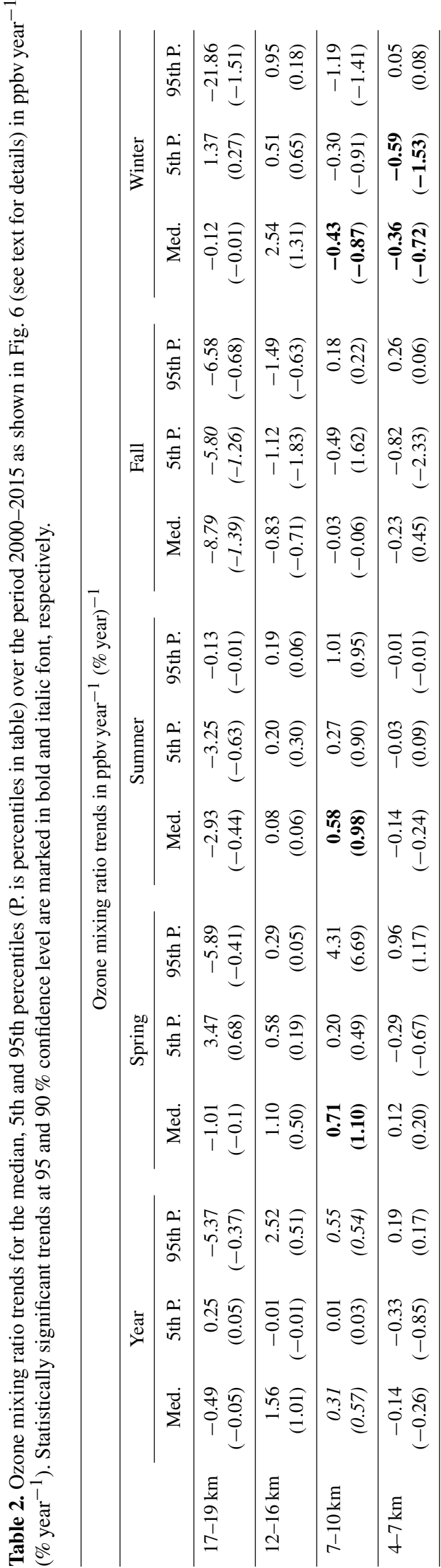

levels in the eastern USA, but not in the western USA (e.g. Copper et al., 2012, 2014). This different regional behavior has been attributed to the inflow of elevated ozone, mainly from East Asia, and to the increasing contribution of stratospheric intrusions (Cooper et al., 2010; Jacob et al., 1999; Parrish et al., 2009; Reidmiller et al., 2009; Lin et al., 2012a, 2015a: Lefohn et al., 2011, 2012). But again, differences in sampling can impact significantly the interpretation of our trend estimates. As pointed out by Lin et al. (2015b), further coordination efforts at both global and regional scales are necessary in order to reduce biases introduced by inhomogeneity in sampling.

\subsection{Characterization of the air masses sounded by the TMF tropospheric ozone lidar}

In an attempt to characterize the air parcels sounded by lidar above TMF based on their travel history and analyze the influence of the different source regions on the ozone profiles, 12-day backward trajectories ending at TMF between 5 and $14 \mathrm{~km}$ altitude were computed using the HYSPLIT4 model (Draxler and Rolph, 2003; http://www.arl.noaa.gov/ready/ hysplit4.html). The NCAR/NCEP Reanalysis pressure level data were used as meteorological input (Kalnay et al., 1996) in HYSPLIT4. These data, available since 1948, have provided 4-times-daily meteorological information at 17 pressure levels between the 1000 and $10 \mathrm{hPa}$ and $2.5 \times 2.5^{\circ}$ horizontal resolution. Several studies (Harris et al., 2005; Stohl and Seibert, 1998) provided a wide range of uncertainty estimates along the trajectories. The more recent study by Engström and Magnusson (2009) indicates that the uncertainty of the trajectories is within $354-400 \mathrm{~km}$ before 4 days and $600 \mathrm{~km}$ after.

Our trajectory analysis comprises two steps. First, the 12day backward trajectories computed by HYSPLIT and ending at different altitude levels were grouped using the HYSPLIT clustering tool (Draxler et al., 2009) in order to identify the most significant paths followed by the air masses arriving over the station. Based on the results of this preliminary analysis, five main regions were identified: the stratosphere, the Asian boundary layer (ABL), the free-troposphere above Asia (AFT), Central America and the Pacific Ocean. Once these geographical areas were identified, we performed a classification of the air parcels according to the criteria described next.

An air parcel was classified as "Stratospheric" if the 12-day backward trajectory intercepted the tropopause and resided at least $12 \mathrm{~h}$ above the local tropopause. The tropopause height information comes from the global tropopause height data derived once a day by the NOAA Physical Sciences Division (http://www.esrl.noaa.gov/psd) from the same NCAR/NCEP Reanalysis database used as input to HYSPLIT4. Computations are based on the World Meteorological Organization (WMO, 1957) definition, that is, the lowest height at which the temperature lapse rate be- 
Table 3. Standard errors in ppbv year ${ }^{-1}$ and $p$ values associated with ozone mixing ratio trends for the median, 5th and 95th percentiles (P. is percentiles in table) included in Table 2 and shown in Fig. 6. Data corresponding to statistically significant trends at 95 and $90 \%$ confidence level are marked in bold and italic font, respectively.

\begin{tabular}{|c|c|c|c|c|c|c|c|c|c|c|c|c|c|c|c|}
\hline \multicolumn{16}{|c|}{ Ozone mixing ratio trend standard errors in ppbv year ${ }^{-1}\left(\%\right.$ year $\left.{ }^{-1}\right)$} \\
\hline & \multicolumn{3}{|c|}{ Year } & \multicolumn{3}{|c|}{ Spring } & \multicolumn{3}{|c|}{ Summer } & \multicolumn{3}{|c|}{ Fall } & \multicolumn{3}{|c|}{ Winter } \\
\hline & Med. & 5th P. & 95th P. & Med. & 5th P. & 95th P. & Med. & 5th P. & 95th P. & Med. & 5 th P. & 95th P. & Med. & 5th P. & 95th P. \\
\hline $17-19 \mathrm{~km}$ & $\begin{array}{r}3.58 \\
(0.09)\end{array}$ & $\begin{array}{r}3.12 \\
(0.62)\end{array}$ & $\begin{array}{r}6.22 \\
(0.43)\end{array}$ & $\begin{array}{r}6.79 \\
(0.67)\end{array}$ & $\begin{array}{r}4.76 \\
(0.93)\end{array}$ & $\begin{array}{r}8.71 \\
(0.61)\end{array}$ & $\begin{array}{r}2.57 \\
(0.39)\end{array}$ & $\begin{array}{r}3.88 \\
(0.75)\end{array}$ & $\begin{array}{r}5.32 \\
(4.09)\end{array}$ & $\begin{array}{r}4.47 \\
(0.71)\end{array}$ & $\begin{array}{r}2.92 \\
(0.63)\end{array}$ & $\begin{array}{l}11.77 \\
(1.22)\end{array}$ & $\begin{array}{r}7.06 \\
(0.59)\end{array}$ & $\begin{array}{r}5.90 \\
(1.16)\end{array}$ & $\begin{array}{r}0.82 \\
(0.06)\end{array}$ \\
\hline $12-16 \mathrm{~km}$ & $\begin{array}{r}1.21 \\
(0.78)\end{array}$ & $\begin{array}{r}0.39 \\
(0.39)\end{array}$ & $\begin{array}{r}4.66 \\
(0.94)\end{array}$ & $\begin{array}{r}1.83 \\
(0.83)\end{array}$ & $\begin{array}{r}0.89 \\
(0.29)\end{array}$ & $\begin{array}{r}5.95 \\
(1.03)\end{array}$ & $\begin{array}{r}0.83 \\
(0.62)\end{array}$ & $\begin{array}{r}0.51 \\
(0.77)\end{array}$ & $\begin{array}{r}3.76 \\
(1.18)\end{array}$ & $\begin{array}{r}1.10 \\
(0.94)\end{array}$ & $\begin{array}{r}0.85 \\
(1.39)\end{array}$ & $\begin{array}{r}3.84 \\
(1.62)\end{array}$ & $\begin{array}{r}2.54 \\
(1.31)\end{array}$ & $\begin{array}{r}1.16 \\
(1.48)\end{array}$ & $\begin{array}{l}10.05 \\
(1.90)\end{array}$ \\
\hline $7-10 \mathrm{~km}$ & $\begin{array}{r}0.15 \\
(0.28)\end{array}$ & $\begin{array}{r}0.19 \\
(0.57)\end{array}$ & $\begin{array}{r}0.30 \\
(0.29)\end{array}$ & $\begin{array}{r}0.25 \\
(0.39)\end{array}$ & $\begin{array}{r}0.38 \\
(0.93)\end{array}$ & $\begin{array}{r}3.32 \\
(5.15)\end{array}$ & $\begin{array}{r}0.28 \\
(0.47)\end{array}$ & $\begin{array}{r}0.20 \\
(0.07)\end{array}$ & $\begin{array}{r}1.20 \\
(1.13)\end{array}$ & $\begin{array}{r}0.25 \\
(0.50)\end{array}$ & $\begin{array}{r}0.35 \\
(1.16)\end{array}$ & $\begin{array}{r}0.97 \\
(1.19)\end{array}$ & $\begin{array}{r}0.18 \\
(0.34)\end{array}$ & $\begin{array}{r}0.27 \\
(0.82)\end{array}$ & $\begin{array}{r}1.00 \\
(1.60)\end{array}$ \\
\hline $4-7 \mathrm{~km}$ & $\begin{array}{r}0.14 \\
(0.26)\end{array}$ & $\begin{array}{r}0.24 \\
(0.62)\end{array}$ & $\begin{array}{r}0.25 \\
(0.22)\end{array}$ & $\begin{array}{r}0.31 \\
(0.52)\end{array}$ & $\begin{array}{r}0.36 \\
(0.83)\end{array}$ & $\begin{array}{r}0.56 \\
(0.68)\end{array}$ & $\begin{array}{r}0.21 \\
(0.36)\end{array}$ & $\begin{array}{r}0.35 \\
(1.05)\end{array}$ & $\begin{array}{r}0.38 \\
(0.56)\end{array}$ & $\begin{array}{r}0.31 \\
(0.61)\end{array}$ & $\begin{array}{r}0.38 \\
(1.08)\end{array}$ & $\begin{array}{r}0.53 \\
(0.12)\end{array}$ & $\begin{array}{r}0.16 \\
(0.32)\end{array}$ & $\begin{array}{r}0.18 \\
(0.47)\end{array}$ & $\begin{array}{r}0.28 \\
(0.45)\end{array}$ \\
\hline \multicolumn{16}{|c|}{$p$ values } \\
\hline & \multicolumn{3}{|c|}{ Year } & \multicolumn{3}{|c|}{ Spring } & \multicolumn{3}{|c|}{ Summer } & \multicolumn{3}{|c|}{ Fall } & \multicolumn{3}{|c|}{ Winter } \\
\hline & Med. & 5th P. & 95th P. & Med. & 5th P. & 95th P. & Med. & 5th P. & 95th P. & Med. & 5th P. & 95th P. & Med. & 5th P. & 95th P. \\
\hline $17-19 \mathrm{~km}$ & 0.89 & 0.94 & 0.40 & 0.88 & 0.48 & 0.51 & 0.27 & 0.41 & 0.98 & 0.07 & 0.07 & 0.60 & 0.99 & 0.82 & 0.17 \\
\hline $12-16 \mathrm{~km}$ & 0.22 & 0.98 & 0.60 & 0.55 & 0.52 & 0.96 & 0.92 & 0.71 & 0.96 & 0.47 & 0.21 & 0.70 & 0.29 & 0.67 & 0.92 \\
\hline $7-10 \mathrm{~km}$ & 0.06 & 0.94 & 0.09 & 0.01 & 0.60 & 0.22 & 0.05 & 0.19 & 0.41 & 0.91 & 0.18 & 0.86 & 0.03 & 0.28 & 0.25 \\
\hline $4-7 \mathrm{~km}$ & 0.33 & 0.19 & 0.44 & 0.70 & 0.44 & 0.11 & 0.52 & 0.92 & 0.98 & 0.47 & 0.05 & 0.63 & 0.04 & $4.10^{-3}$ & 0.85 \\
\hline
\end{tabular}

comes lower than $2 \mathrm{~K} \mathrm{~km}^{-1}$, provided that along $2 \mathrm{~km}$ above this height the average lapse is also lower than $2 \mathrm{~K} \mathrm{~km}^{-1}$. In addition, the NOAA computations do not allow tropopause heights at pressure levels larger than $450 \mathrm{hPa}$ and smaller than $85 \mathrm{hPa}$. The residence time of the air masses in the stratosphere was selected based on a sensitivity test, which indicated that time residences larger than $6 \mathrm{~h}$ already show a significant signature of the stratospheric ozone in the ozone profiles within the troposphere. However, to avoid an overestimation of the stratospheric cases a $12 \mathrm{~h}$ residence time was found to be more appropriate for our analysis.

Next, the air parcels that were not classified as "stratosphere" were then classified as "Central America" for trajectories comprising a minimum residence time of 4 days within the area labeled "Central America" in Fig. 7. According to the sensitivity test, a 4-day residence time period is long enough to avoid the influence of additional source regions and short enough to avoid an underestimation of the "Central America" cases.

The air parcels not classified as "stratosphere", or "Central America" were then classified as Asian if they comprised a minimum residence time of $6 \mathrm{~h}$ within the area labeled as "Asia" in Fig. 7. The Asian trajectories are subdivided in ABL if they come from an altitude below $3 \mathrm{~km}$ and AFT if they come from altitudes above $3 \mathrm{~km}$. According to the sensitivity test, a residence time of $6 \mathrm{~h}$ is enough to clearly identify the signature of Asian emissions on the ozone profiles observed at TMF.

The air parcels not classified in any of the previous categories were classified as "Pacific Ocean" if a minimum residence time of $276 \mathrm{~h}$ (11.5 days) within the area labeled "Pa-

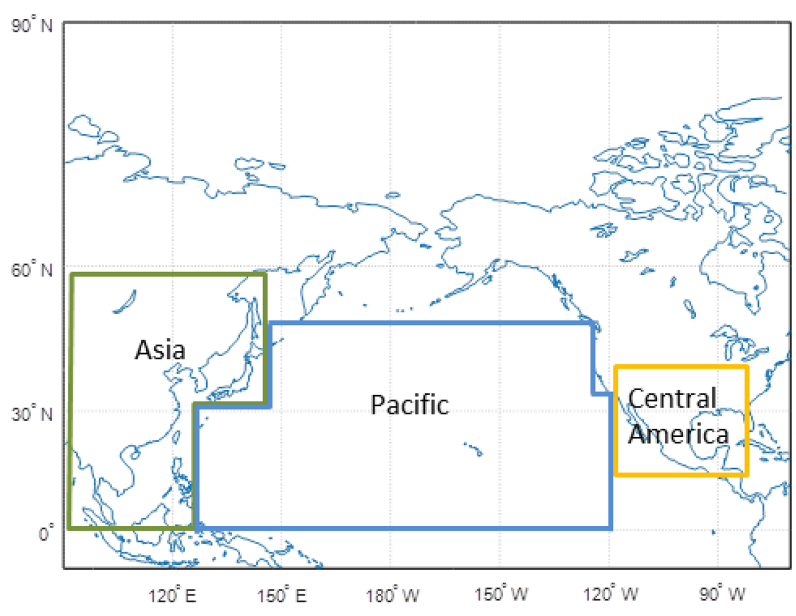

Figure 7. Geographical boundaries used to characterize the air parcels associated with the 12-day backward trajectories ending at TMF during the lidar measurements over the period 2000-2015.

cific" in Fig. 7 was reached. A residence time of $276 \mathrm{~h}$ guarantees that no influence from additional sources affects the air masses reaching TMF and the "Pacific" region can be considered as a background region.

Trajectories that did not match any of the previous categories were grouped as "residual trajectories" (RT). They will be considered for statistical purposes, but not for the analysis of the ozone mixing ratio values.

The classification of the air parcels took place sequentially, which means that each category is exclusive from the others. The classification was made for each of the four seasons sep- 


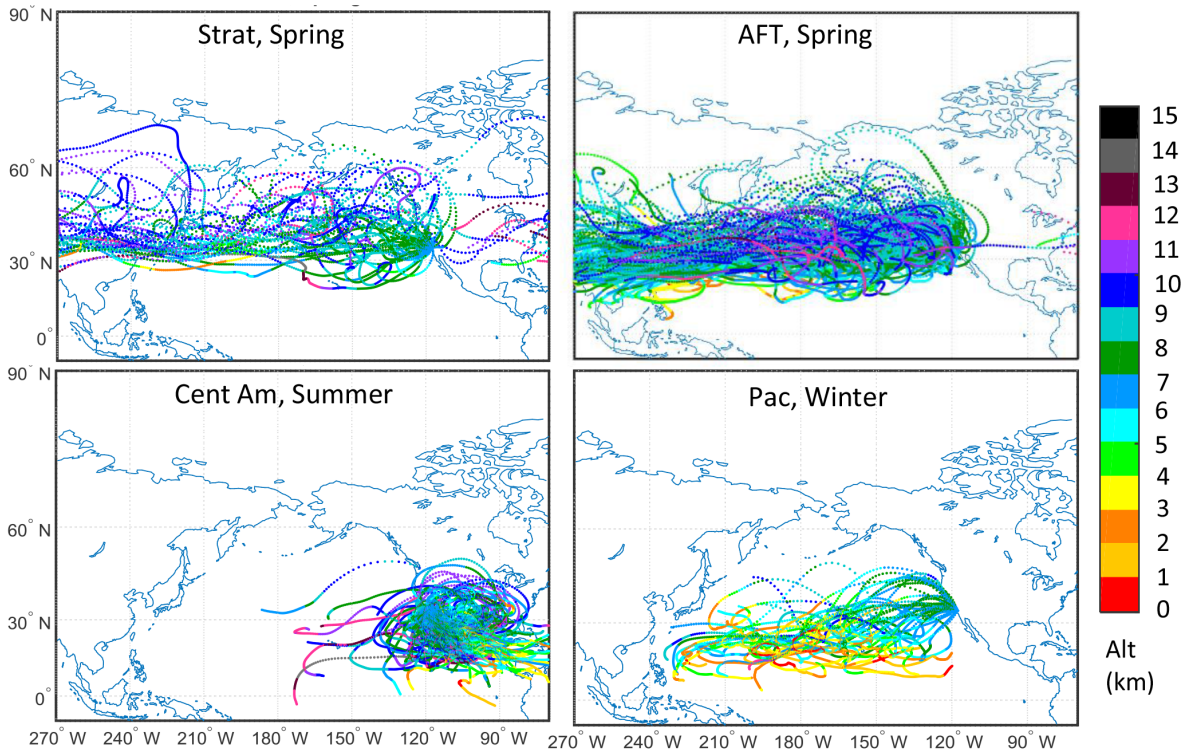

Figure 8. Examples of HYSPLIT 12-day backward trajectories arriving at TMF at $7 \mathrm{~km}$ altitude for four selected seasons and categories (see text for details).

Table 4. Number of air parcels ending at TMF during lidar measurements over the period 2000-2015, classified as "stratosphere", "Central America", "ABL" (Asian boundary layer), "AFT" (Asian free troposphere), "Pacific Ocean" and "RT" (residual trajectories) (see text for details).

\begin{tabular}{lrrrrrr}
\hline & Strat & Cent Am & ABL & AFT & Pac & RT \\
\hline $14 \mathrm{~km}$ & $1161(80 \%)$ & $39(3 \%)$ & $0(0 \%)$ & $102(7 \%)$ & $100(7 \%)$ & $55(4 \%)$ \\
$13 \mathrm{~km}$ & $905(62 \%)$ & $57(4 \%)$ & $5(0 \%)$ & $266(18 \%)$ & $139(10 \%)$ & $85(6 \%)$ \\
$12 \mathrm{~km}$ & $658(45 \%)$ & $78(5 \%)$ & $28(2 \%)$ & $425(29 \%)$ & $168(12 \%)$ & $100(7 \%)$ \\
$11 \mathrm{~km}$ & $426(29 \%)$ & $76(5 \%)$ & $49(3 \%)$ & $523(36 \%)$ & $243(17 \%)$ & $140(10 \%)$ \\
$10 \mathrm{~km}$ & $258(18 \%)$ & $86(6 \%)$ & $82(6 \%)$ & $584(40 \%)$ & $304(21 \%)$ & $143(10 \%)$ \\
$9 \mathrm{~km}$ & $167(11 \%)$ & $85(6 \%)$ & $101(7 \%)$ & $613(42 \%)$ & $296(20 \%)$ & $195(13 \%)$ \\
$8 \mathrm{~km}$ & $123(8 \%)$ & $97(7 \%)$ & $124(9 \%)$ & $572(39 \%)$ & $321(22 \%)$ & $220(15 \%)$ \\
$7 \mathrm{~km}$ & $97(7 \%)$ & $107(7 \%)$ & $122(8 \%)$ & $540(37 \%)$ & $317(22 \%)$ & $274(19 \%)$ \\
$6 \mathrm{~km}$ & $69(5 \%)$ & $137(9 \%)$ & $136(9 \%)$ & $499(34 \%)$ & $330(23 \%)$ & $286(20 \%)$ \\
$5 \mathrm{~km}$ & $72(5 \%)$ & $179(12 \%)$ & $107(7 \%)$ & $472(32 \%)$ & $266(18 \%)$ & $361(25 \%)$ \\
\hline
\end{tabular}

arately in order to account for the seasonal changes in synoptic circulation. Examples of the corresponding classified back trajectories are shown in Fig. 8. The number and frequency of occurrences of each air parcel category for all seasons is compiled in Table 4. A monthly distribution of these occurrences is shown in Fig. 9. With the selection criteria we have set, air masses are predominantly associated with the "AFT" region below $11 \mathrm{~km}$, ranging between 32 and $42 \%$ from 5 to $11 \mathrm{k}$ with maximum number of cases in spring. A very low number of parcels classified as "ABL" are found (between 0 and $9 \%$ ). Increasing influence of the stratosphere is observed at upper levels, with values increasing from $5 \%$ at $5 \mathrm{~km}$ to $80 \%$ at $14 \mathrm{~km}$. Higher influence is observed during winter and spring, which agrees well with previous studies in the western USA (Sprenger, 2003; Stohl, 2003). A statistically significant Central American influence was identified in summer with a frequency of occurrence varying between 12 and $3 \%$, decreasing with altitude. The Central America influence coincides with the establishment of the North American Monsoon circulation from July to September which affects Central America and the southern USA.

Composite ozone profiles and statistical parameters were estimated for each category of air parcel and for altitudes between 5 and $14 \mathrm{~km}$ at $1 \mathrm{~km}$ altitude intervals. Figure 10 shows the ozone mixing ratio mean (open circles), median (red bars), 25th and 75th percentiles (blue bars) at $9 \mathrm{~km}$ altitude for each of the identified categories and season. The number of occurrences for each category is mentioned between parentheses. The ozone statistics obtained when a low number of occurrences was found should be ignored (e.g., Central America except for summer, or ABL for winter and fall). Figure 11a shows, for each season, the composite ozone 


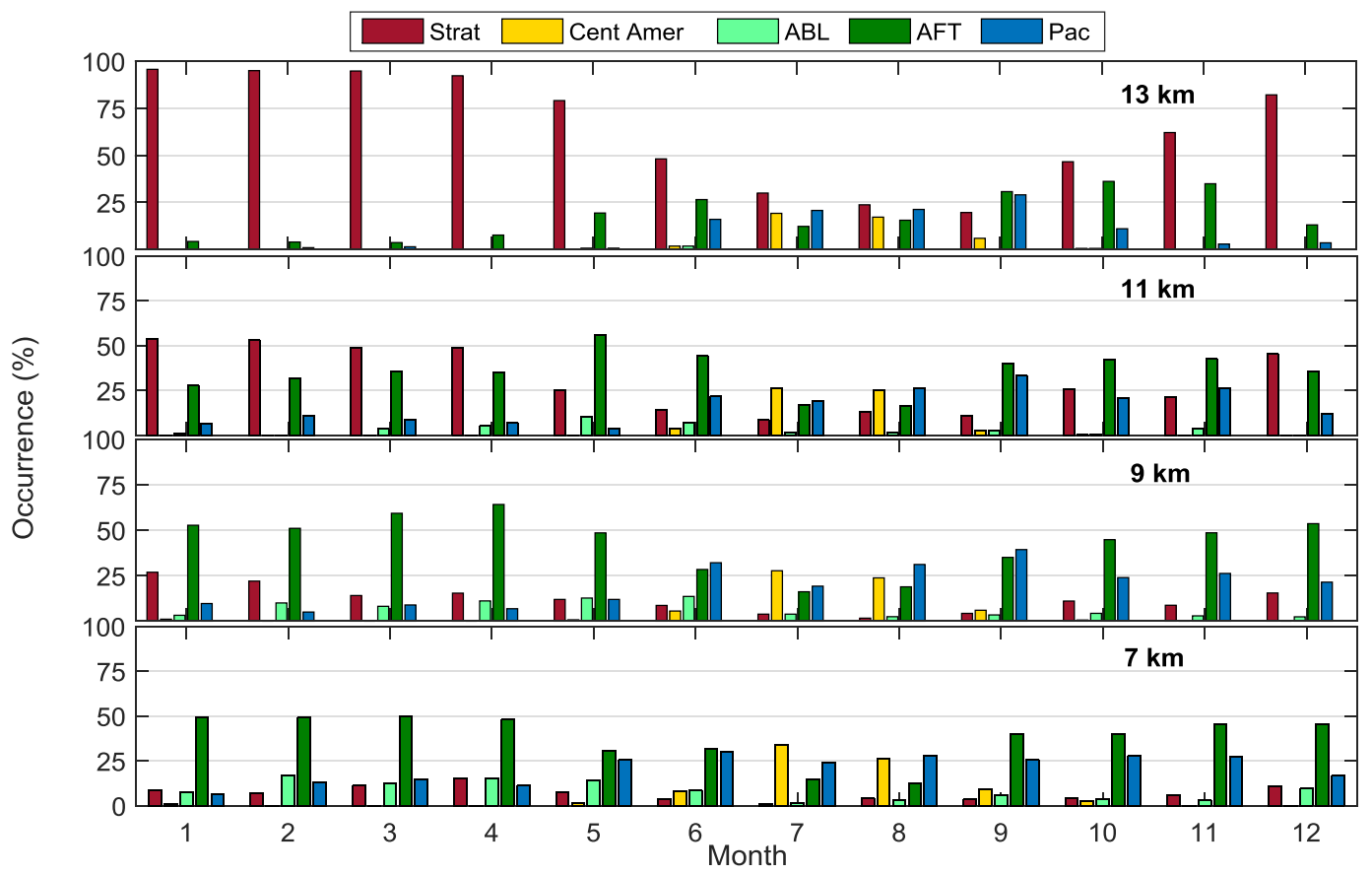

Figure 9. Distribution of the five categories identified for each trajectory ending at TMF during the lidar measurements over the period 2000-2015. The number of occurrences is given in percentage for each month of the year, and for four different altitude layers.

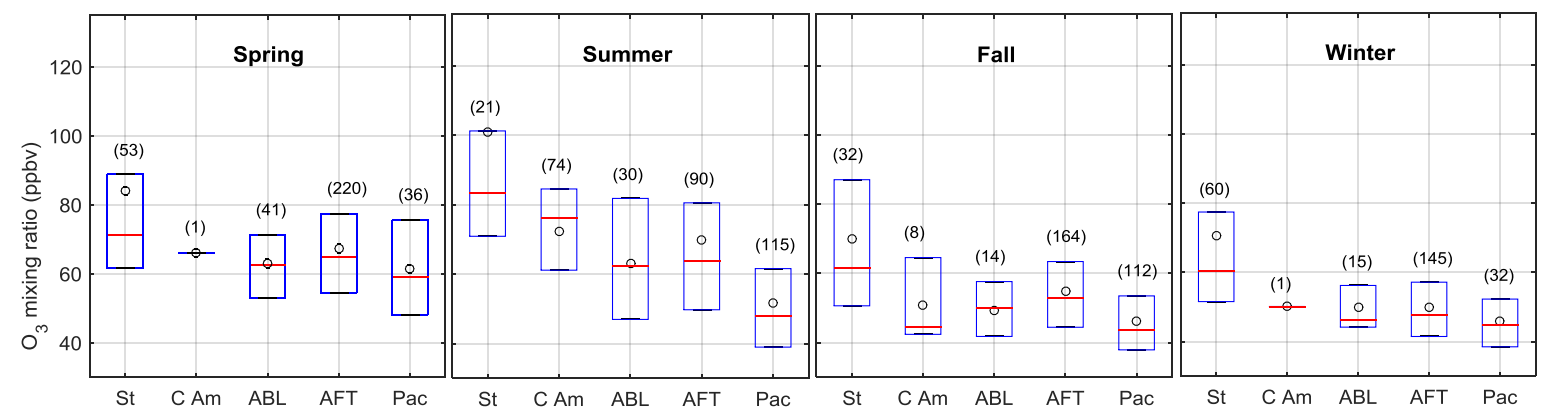

Figure 10. Box plot of the ozone mixing ratios measured within the air masses arriving at TMF at $9 \mathrm{~km}$ for the five identified categories (see text for details) and the four seasons. The black dot represents the mean value, the red line is the median and the box limits correspond to the 25 th and 75 th percentiles. The numbers between parentheses indicate the number of associated trajectories.

profiles constructed from the ozone mixing ratio median values found for a particular category at a given altitude. The same profiles, but focused on the troposphere $(5-10 \mathrm{~km})$, are shown in Fig. 11b. In order to keep the most statistically significant results, composite values computed using less than $5 \%$ of the total number of samples for a given season were not plotted, leaving out certain sections of the composite profiles.

Not surprisingly, the analysis reveals that the largest ozone mixing ratio values were mostly observed when the air masses were classified as "stratospheric" regardless of the season (median values between 17 and 35 ppbv larger than for the Pacific Ocean at $9 \mathrm{~km}$ ). In spring and winter, the influence of the stratosphere goes down to $5 \mathrm{~km}$, with ozone values ranging from 3 to 13 ppbv larger than for the Pacific category below $9 \mathrm{~km}$. For this category, large ozone variability was found, as indicated by the 25th and 75th percentiles in Fig. 10. As altitude increases, the influence of the stratosphere is more important, exceeding $40 \%$ above $12 \mathrm{~km}$, resulting in higher ozone mixing ratio values (red curves in Fig. 11).

Conversely, low ozone mixing ratio values (40-61 ppbv below $9 \mathrm{~km}$ ) were consistently associated with the air parcels classified as "Pacific Ocean" (cyan curves). This region can be considered as a source of "background ozone", since no anthropogenic source is expected to affect the local ozone budget. 

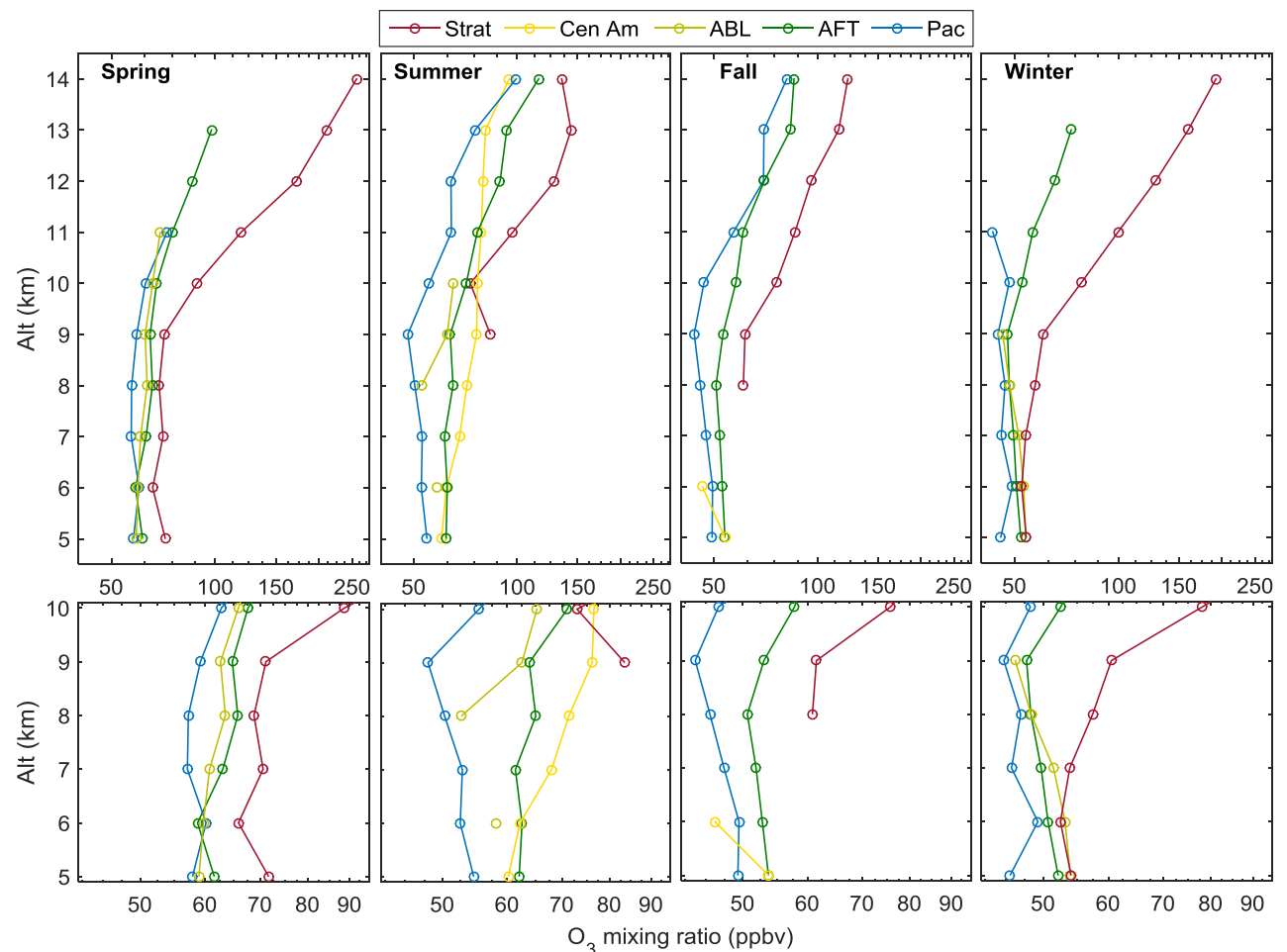

Figure 11. (a) Composite profiles of the ozone mixing ratio associated with the different categories and for each season. Results are shown only when the number of samples for a given category was larger than $5 \%$ of the total number of samples in that season. (b) Same as panel (a) but zoomed in the region from 5 to $10 \mathrm{~km}$.

Higher ozone content (from 2 to 13 ppbv higher than for the Pacific region) is systematically found for air parcels classified as "AFT". Values are especially larger in summer, when differences of at least 8 ppbv with the Pacific region are found for altitudes between 5 and $13 \mathrm{~km}$. In general, the number of occurrences for air parcels classified as "ABL" remains very small to provide any meaningful interpretation. Nonetheless, values in the lower part of the troposphere during spring and winter, when the number of occurrences is higher, are similar to those observed for the AFT. The occurrence of the Asian air masses is mostly observed in spring (Figs. 9 and 10), and ozone associated with Asian emissions has been frequently detected in the western USA during this season in previous studies (e.g., Cooper et al., 2005b; Zhang et al., 2008; Lin et al., 2012b). Even though less frequent, our results indicate that Asian pollution episodes observed during summer are associated with larger ozone values than in spring. These larger values are due to more active photochemical ozone production observed over China in summer (Verstraeten et al., 2015), associated with larger ozone values than those in spring. The influence of the air parcels classified as Central America is mainly observed during summer, with ozone median values 5-28 ppbv larger than those observed for the Pacific region between 5 and $9 \mathrm{~km}$ (yellow curve in Fig. 11). Ozone mean values of $72 \mathrm{ppbv}$ were found at $9 \mathrm{~km}$ altitude for the 74 air parcels classified as
"Central America" (Fig. 10). The corresponding values for the 115 air parcels classified as "Pacific Ocean" are about $52 \mathrm{ppbv}$, which is $20 \mathrm{ppbv}$ lower. The larger ozone values associated with the "Central America" category possibly points to the lightning-induced enhancement of ozone within the more frequent occurrence of thunderstorms during the North American summer monsoon. Previous studies (Cooper et al., 2009), have observed enhanced ozone values associated with the North American Monsoon, mainly due to ozone production associated with lightning (Choi et al., 2009; Cooper et al., 2009). However, this feature was observed in the eastern USA. Because of the synoptic conditions during the monsoon, the western USA is not as much influenced and no significant regional ozone increase was reported (Barth et al., 2012; Cooper et al., 2009). Nevertheless, Cooper et al. (2009) reported higher modeled lightning-induced $\mathrm{NO}_{x}$ concentrations at TMF than at other western locations, which would be consistent with our findings. Further investigation, including a detailed history of the meteorological conditions along the trajectories and chemistry transport model data, is needed to confirm this correlation. Additional sources, such as ozone transport from Central America or even mixing with different sources (e.g., the stratosphere) should also be considered. 


\subsection{The influence of tropopause folds on the TMF tropospheric ozone record}

In the previous section, a large variability in the composite ozone content was found for the air parcels classified as "Stratospheric". In the current section, we provide at least one clear explanation for this large variability. Tropopause folds are found primarily in the vicinity of the subtropical jets, in the $20-50^{\circ}$ latitude range. They typically consist of 3-D folds of the virtual surface separating air masses of tropospheric characteristics (weakly stratified, moist, low ozone concentration, etc.) and those of stratospheric characteristics (highly stratified, dry, high ozone concentration, etc.). Tropopause folds can result in the transport of large amounts of stratospheric ozone into the troposphere, reaching in some cases the planetary boundary layer and enhancing ozone amounts even at the surface (Chung and Dann, 1985; Langford et al., 2012; Lefohn et al., 2012; Lin et al., 2012a). They are considered one of the main mechanisms of stratosphere-troposphere exchange and have been widely studied in the past (e.g., Bonasoni and Evangelisti, 2000; Danielsen and Mohnen, 1977; Lefohn et al., 2011; Vaughan et al., 1994; Yates et al., 2013). Due to the location of TMF, the upper troposphere above the site is frequently impacted by tropopause folds.

Double tropopauses are usually expected to result from tropopause folds in the layer between the two identified tropopauses. Therefore, a common method used in the literature to identify tropopause folds is to detect the presence of double tropopauses based on temperature profiles (e.g., Chen et al., 2011). The MERRA (Modern-Era Retrospective analysis for Research and Applications; Rienecker et al., 2011) reanalysis data $\left(1 \mathrm{~km}\right.$ vertical resolution, $1 \times 1.25^{\circ}$ horizontal resolution) were used in this study to identify the presence of double tropopauses above the station. A comparison between the MERRA temperature profiles and the temperature profiles measured by the radiosondes launched at TMF was performed in order to evaluate the performance of MERRA above the site. The comparison (not shown) reveals excellent agreement, with average relative differences of $2 \%$ or less from the surface up to $25 \mathrm{~km}$. The heights of double tropopauses were computed following a methodology similar to that proposed in Chen et al. (2011) and Randel et al. (2007). The first (lower) tropopause is identified according to the WMO definition, as explained earlier. A second (upper) tropopause is identified above the WMO tropopause if the temperature lapse rate increases over $3 \mathrm{~K} \mathrm{~km}^{-1}$ within at least $1 \mathrm{~km}$, and its height is determined once again by the WMO criterion.

Using this methodology, we found that $27 \%$ of the TMF tropospheric ozone lidar profiles were measured in the presence of double tropopauses. This high frequency of double tropopause occurrences was expected considering the latitude of TMF, i.e., near the subtropical jet, where frequent tropopause folds occur. Figure 12 shows the number of cases

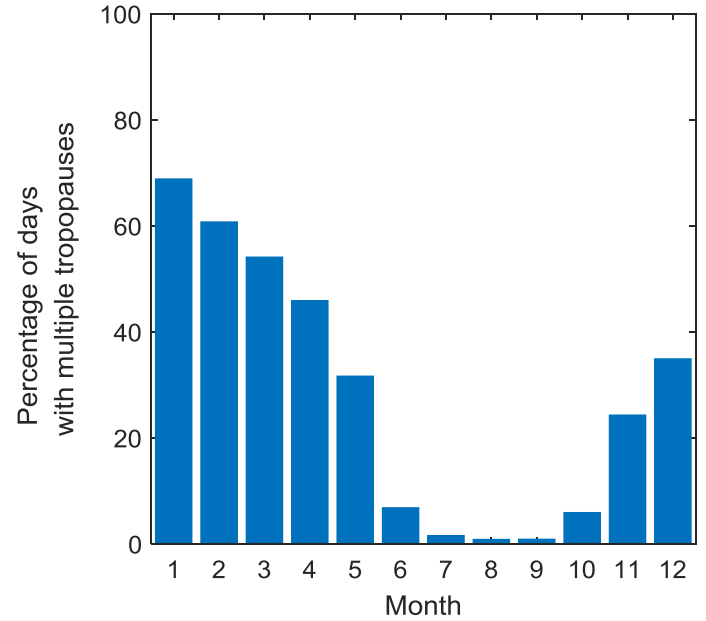

Figure 12. Monthly distribution of occurrences (in \%) of double tropopauses above TMF. The number of days with tropopause folds is normalized to the total number of measurements per month compiled in Table 1.

with double tropopauses above TMF distributed per months, with the number of days with double tropopause being normalized to the total number of measurements every month (compiled in Table 1). As we can see, the presence of double tropopauses was especially frequent during winter and spring, which coincides with the higher frequency of stratospheric air masses arriving at TMF estimated by the backward trajectories analysis (Fig. 9) and is in agreement with previous studies (Randel et al., 2007). The altitude of detected single tropopauses is found around $13 \mathrm{~km}$ in winter and spring, and 16-17 km in summer and fall (Fig. 13a-d). When a double tropopause is identified, the altitude of the lower tropopause ranges between 8 and $15 \mathrm{~km}$, with the distribution peak centered around $12-13 \mathrm{~km}$ (Fig. 13e-h), and the second tropopause is detected typically around $17-18 \mathrm{~km}$ (Fig. 13i-1).

Figure 14a shows an example of an ozone profile measured on 8 January 2013, when a double tropopause was detected above TMF. The average of all tropospheric ozone lidar profiles measured in winter in cases of single tropopause is plot as reference. In Fig. 14b, the average of all tropospheric ozone lidar profiles measured in winter (blue curves) and spring (red curves) in the presence of a double tropopause (solid curves), and in the presence of a single tropopause (dashed curves) are included. The right panel (Fig. 14c) is simply a lower tropospheric-zoomed version of the middle panel (Fig. 14b). Only winter and spring are shown because they are the seasons most affected by double tropopause cases as previously stated. In the presence of double tropopauses a clear dual vertical structure in ozone is observed. For the specific case on 8 January 2013 (Fig. 14a), the lower tropopause was located at $9 \mathrm{~km}$ and stratospheric air reached down to approximately $6 \mathrm{~km}$, considerably in- 


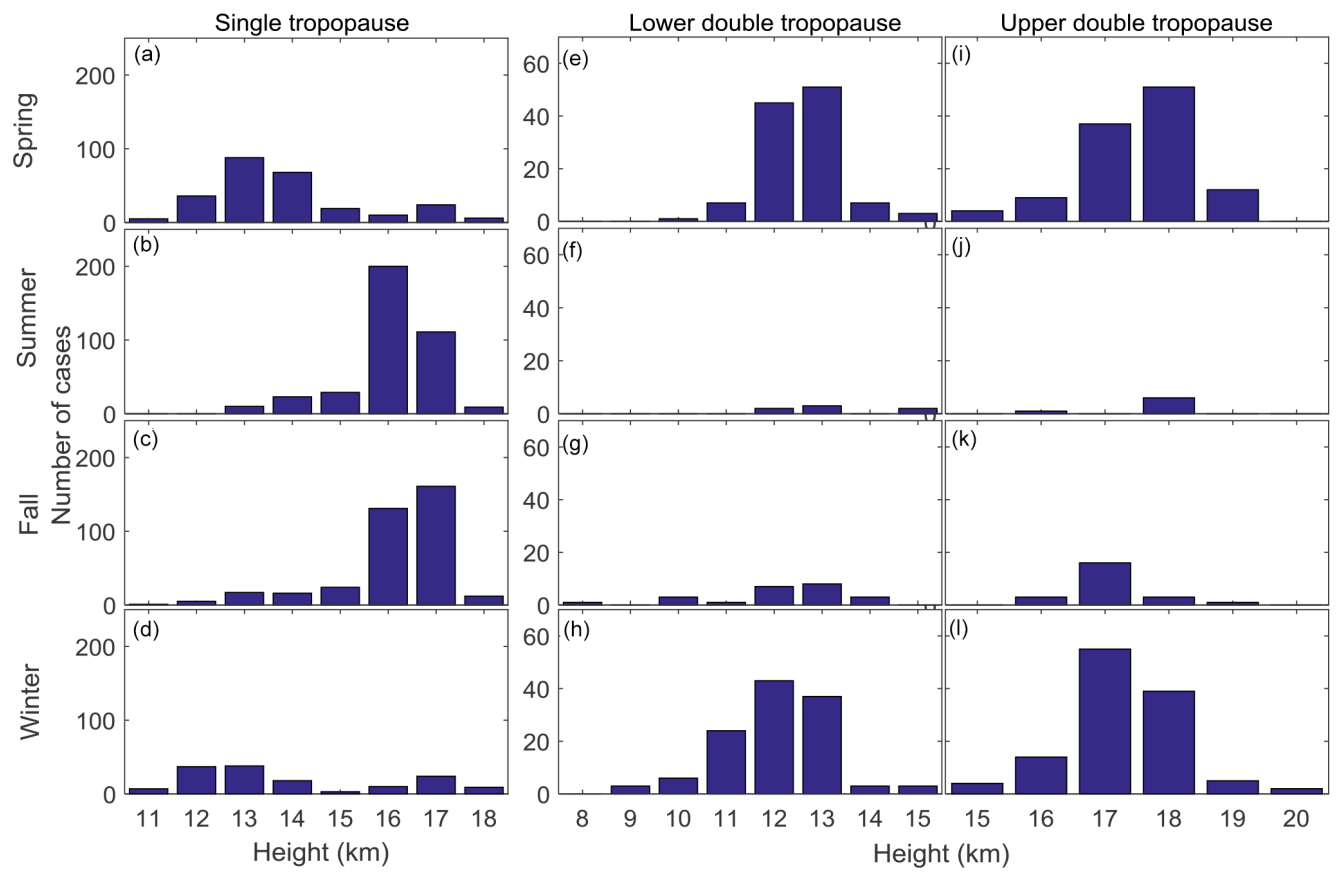

Figure 13. (a-d) Altitude distribution of the tropopause above TMF for spring, summer, fall and winter, respectively, and in the absence of double-tropopause. (e-h) Altitude distribution of the lower (first) tropopause above TMF for spring, summer, fall and winter, respectively, and in the presence of a double-tropopause. (i-l) Same as panels (e-h) but for the upper or second tropopause. All computations were made at the times of the TMF lidar measurements.
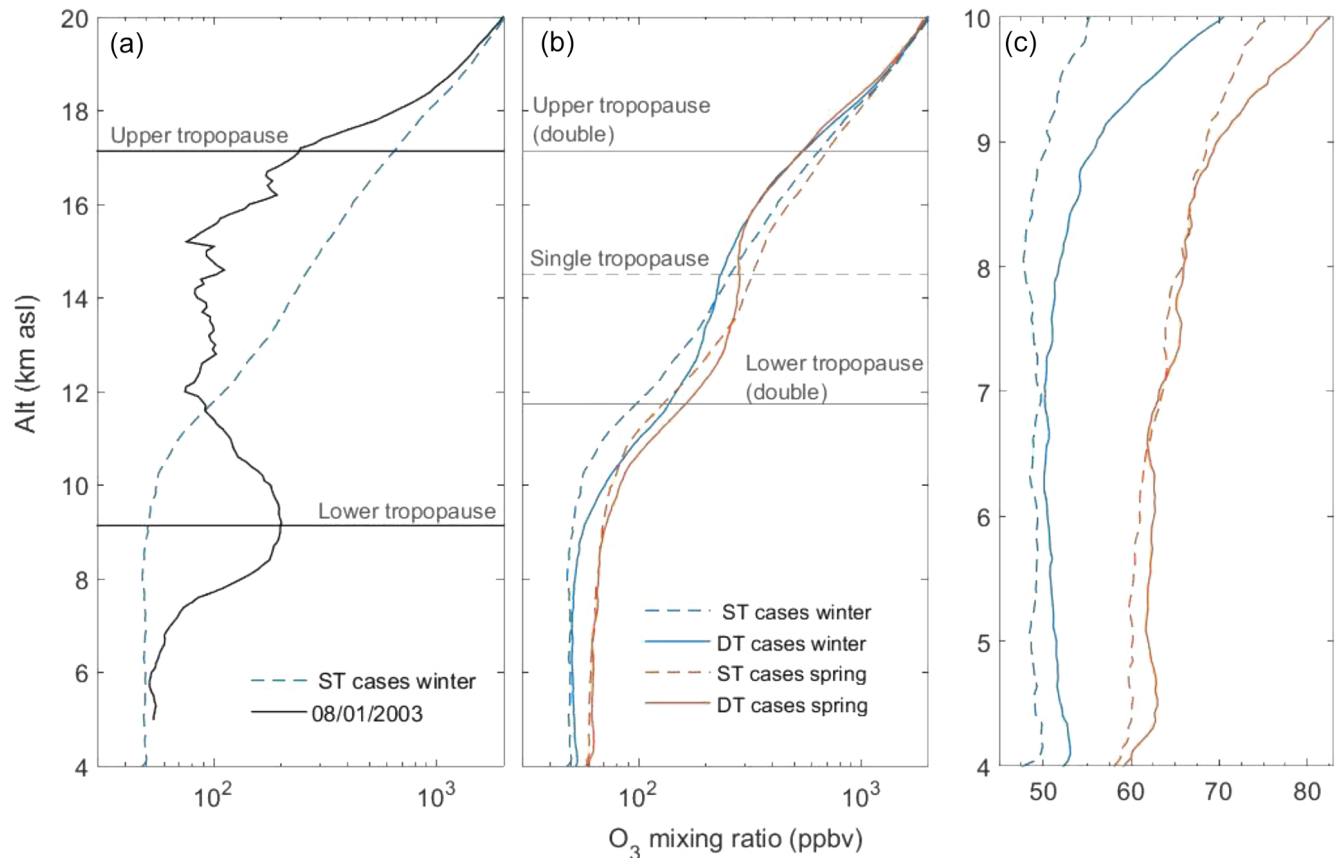

Figure 14. (a) Ozone mixing ratio profile on 8 January 2003 (black line) and winter averaged ozone mixing ratio profile computed in the presence of single tropopause above TMF (blue dashed line). The horizontal solid black lines depict the altitude of the lower and upper tropopauses on 8 June 2013. (b) Winter- and spring-averaged (cyan and red, respectively) ozone mixing ratio profiles computed in the presence of a double tropopause (DT, solid curves) and single tropopause (ST, dashed curves). The horizontal solid grey lines depict the average altitude of the lower and upper tropopauses when a double tropopause was identified. The horizontal dashed grey line corresponds to the average altitude of the tropopause when a single tropopause was identified. (c) Same as panel (b) but zoomed on the tropospheric part of the profiles $(4-10 \mathrm{~km})$. 
creasing the ozone content in the troposphere. On the other hand, ozone values were lower than the winter average in the lower stratosphere (11-19 km). In the case of the average profiles (Fig. 14b), the dual vertical structure presents higher ozone values between 12 and $14 \mathrm{~km}$ and lower mixing ratio values between 14 and $18 \mathrm{~km}$. The dual ozone structure observed by lidar coincides with the expected location of the fold, and consists of systematically higher-than-average mixing ratios in the lower half of the fold $(12-14 \mathrm{~km})$, and lowerthan-average mixing ratios in the upper half of the fold (14$18 \mathrm{~km})$. This dual structure is consistent with the expected origin of the air masses within a tropopause fold. Stratospheric air, richer in ozone, is measured within the lower half of the fold, while tropospheric ozone-poor air is measured within the upper half of the fold.

In the case of deep stratospheric intrusions, ozone-rich stratospheric air masses embedded in the lower half of the fold can reach lower altitudes, and occasionally the planetary boundary layer mixing down to the surface (Chung and Dann, 1985; Langford et al., 2012, 2015; Lefohn et al., 2012; Lin et al., 2012a), leading to an ozone increase in the lower troposphere (Fig. 14b). In our case, the mean increase is around 2 ppbv below $6 \mathrm{~km}$ for both spring and winter. This increase is consistent with previous reports of the importance of the stratosphere as an ozone source in the lower troposphere (Cooper et al., 2005a; Langford et al., 2012; Lefohn et al., 2011; Trickl et al., 2011), with a 25 to $50 \%$ contribution to the tropospheric budget (Davies and Schuepbach, 1994; Ladstätter-Weißenmayer et al., 2004; Roelofs and Lelieveld, 1997; Stevenson et al., 2006).

\section{Concluding remarks}

Combined ozone photometer surface measurements (20132015) and tropospheric ozone DIAL profiles (2000-2015) at the JPL-Table Mountain Facility were presented for the first time. The high ozone values and low interannual and diurnal variability measured at the surface, typical of high elevation remote sites with no influence of urban pollution, constitute a good indicator of background ozone conditions over the southwestern USA.

The 16-year tropospheric ozone lidar time series is one of the longest lidar records available and is a valuable data set for trend analysis in the western USA, where the number of long-term observations with high vertical resolution in the troposphere is very scarce. A statistically significant positive trend was observed in the upper troposphere, in agreement with previous studies. This ozone increase points out to the influence of long-range transport and/or a change in stratospheric influence, since ozone precursor emissions have been decreasing in the USA over the past 2 decades.

Influence of five main regions (stratosphere, Central America, Asian boundary layer, Asian free troposphere and Pacific Ocean) on the ozone profiles sampled above TMF was detected using 12-day backward trajectories. This trajectories analysis revealed the large influence of the stratosphere, especially in the UTLS and the upper troposphere, leading to high ozone values. The influence of the stratosphere reached down to $5 \mathrm{~km}$ in spring and winter, with ozone values ranging from 3 to 13 ppbv larger than for the Pacific category, considered as a background region. In summer, enhanced ozone values (5-28 ppbv larger than for the Pacific region) were found in air parcels originating from Central America, probably due to the enhanced thunderstorm activity during the North American Monsoon. Frequent air masses coming from Asia were also observed, mainly in spring, associated with ozone values 2 to 13 ppbv larger than those from the background region. Ozone vertical distribution above TMF is also affected by the frequent occurrence of tropopause folds. A dual vertical structure in ozone within the fold layer was clearly observed, characterized by aboveaverage values in the bottom half of the fold (12-14 km), and below-averaged values in the top half of the fold (14-18 km). Above-average ozone values were also observed near the surface (+2 ppbv) on days with a tropopause fold. The high frequency of tropopause folds observed above the site is not surprising given Table Mountain's position in the vicinity of the subtropical jet.

\section{Data availability}

Part of the data used in this publication were obtained as part of the Network for the Detection of Atmospheric Composition Change (NDACC) and are publicly available (see http://www.ndacc.org; Leblanc, 2016). For additional data or information please contact the authors.

Acknowledgements. The work described in this paper was carried out at the Jet Propulsion Laboratory, California Institute of Technology, under a Caltech Postdoctoral Fellowship sponsored by the NASA Tropospheric Chemistry Program. Support for the lidar, surface and ozonesonde measurements was provided by the NASA Upper Atmosphere Research Program. The authors would like to thank M. Brewer, T. Grigsby, J. Howe and members of the JPL lidar team, who assisted in the collection of the data used here. The authors gratefully acknowledge the NOAA Air Resources Laboratory (ARL) for the provision of the HYSPLIT transport and dispersion model and/or READY website (http://www.ready.noaa.gov) and the NCEP/NCAR Reanalysis team for the data used in this publication. We would also like to thank Susan Strahan and the MERRA Reanalysis team for providing the data used in this study and to acknowledge the California Air Resources Board for providing the surface ozone data.

Edited by: V.-H. Peuch

Reviewed by: M. J. Newchurch and one anonymous referee 


\section{References}

Barth, M. C., Lee, J., Hodzic, A., Pfister, G., Skamarock, W. C., Worden, J., Wong, J., and Noone, D.: Thunderstorms and upper troposphere chemistry during the early stages of the 2006 North American Monsoon, Atmos. Chem. Phys., 12, 11003-11026, doi:10.5194/acp-12-11003-2012, 2012.

Bonasoni, P. and Evangelisti, F.: Stratospheric ozone intrusion episodes recorded at Mt. Cimone during the VOTALP project: case studies, Atmos. Environ., 34, 1355-1365, 2000.

Brodin, M., Helmig, D., and Oltmans, S.: Seasonal ozone behavior along an elevation gradient in the Colorado Front Range Mountains, Atmos. Environ., 44, 5305-5315, doi:10.1016/j.atmosenv.2010.06.033, 2010.

Brown-Steiner, B. and Hess, P.: Asian influence on surface ozone in the United States: A comparison of chemistry, seasonality, and transport mechanisms, J. Geophys. Res., 116, 1-13, doi:10.1029/2011JD015846, 2011.

Bufton, J. L., Stewart, R. W., and Weng, C.: Remote measurement of tropospheric ozone, Appl. Optics, 18, 3363-4, doi:10.1364/AO.18.003363, 1979.

Chen, X. L., Ma, Y. M., Kelder, H., Su, Z., and Yang, K.: On the behaviour of the tropopause folding events over the Tibetan Plateau, Atmos. Chem. Phys., 11, 5113-5122, doi:10.5194/acp11-5113-2011, 2011.

Choi, Y., Kim, J., Eldering, A., Osterman, G., Yung, Y. L., Gu, Y., and Liou, K. N.: Lightning and anthropogenic $\mathrm{NO}_{x}$ sources over the United States and the western North Atlantic Ocean: Impact on OLR and radiative effects, Geophys. Res. Lett., 36, L17806, doi:10.1029/2009GL039381, 2009.

Chung, Y. and Dann, T.: Observations of stratospheric ozone at the ground level in Regina, Canada, Atmos. Environ., 19, 157-162, 1985.

Cooper, O. R., Forster, C., Parrish, D., Trainer, M., Dunlea, E., Ryerson, T., Hübler, G., Fehsenfeld, F., Nicks, D., Holloway, J., de Gouw, J., Warneke, C., Roberts, J. M., Flocke, F., and Moody, J.: A case study of transpacific warm conveyor belt transport: Influence of merging airstreams on trace gas import to North America, J. Geophys. Res., 109, D23S08, doi:10.1029/2003JD003624, 2004.

Cooper, O. R., Stohl, A., Hüler, G., Hsie, E. Y., Parrish, D. D., Tuck, A. F., Kiladis, G. N., Oltmans, S. J., Johnson, B. J., Shapiro, M., and Moody, J. L.: Direct transport of midlatitude stratospheric ozone into the lower troposphere and marine boundary layer of the tropical Pacific Ocean, J. Geophys. Res., 110, D23310, doi:10.1029/2005JD005783, 2005a.

Cooper, O. R., Stohl, A., Eckhardt, S., Parrish, D. D., Oltmans, S. J., Johnson, B. J., Nédélec P., Schmidlin, F. J., Newchurch, M. J., Kondo, Y., and Kita, K.: A springtime comparison of tropospheric ozone and transport pathways on the east and west coasts of the United States, J. Geophys. Res., 110, D05S90, doi:10.1029/2004JD005183, 2005b.

Cooper, O. R., Eckhardt, S., Crawford, J. H., Brown, C. C., Cohen, R. C., Bertram, T. H., Wooldridge, P., Perring, A., Brune, W. H., Ren, X., Brunner, D., and Baughcum, S. L.: Summertime buildup and decay of lightning $\mathrm{NO}_{x}$ and aged thunderstorm outflow above North America, J. Geophys. Res., 114, D01101, doi:10.1029/2008JD010293, 2009.

Cooper, O. R., Parrish, D. D., Stohl, A., Trainer, M., Nédélec, P., Thouret, V., Cammas, J. P., Oltmans, S. J., Johnson, B. J., Tara- sick, D., Leblanc, T., McDermid, I. S., Jaffe, D., Gao, R., Stith, J., Ryerson, T., Aikin, K., Campos, T., Weinheimer, A., and Avery, M. A.: Increasing springtime ozone mixing ratios in the free troposphere over western North America, Nature, 463, 344-348, doi:10.1038/nature08708, 2010.

Cooper, O. R., Gao, R.-S., Tarasick, D., Leblanc, T., and Sweeney, C.: Long-term ozone trends at rural ozone monitoring sites across the United States, 1990-2010, J. Geophys. Res., 117, D22307, doi:10.1029/2012JD018261, 2012.

Cooper, O. R., Parrish, D. D., Ziemke, J., Balashov, N. V., Cupeiro, M., Galbally, I. E., Gilge, S., Horowitz, L., Jensen, N. R., Lamarque, J.-F., Naik, V., Oltmans, S. J., Schwab, J., Shindell, D. T., Thompson, A. M., Thouret, V., Wang, Y., and Zbinden, R. M.: Global distribution and trends of tropospheric ozone: An observation-based review, Elem. Sci. Anthr., 2, 000029, doi:10.12952/journal.elementa.000029, 2014.

Cui, J., Sprenger, M., Staehelin, J., Siegrist, A., Kunz, M., Henne, S., and Steinbacher, M.: Impact of stratospheric intrusions and intercontinental transport on ozone at Jungfraujoch in 2005: comparison and validation of two Lagrangian approaches, Atmos. Chem. Phys., 9, 3371-3383, doi:10.5194/acp-9-3371-2009, 2009.

Danielsen, E. F. and Mohnen, V. A.: Project dustorm report: ozone transport, in situ measurements, and meteorological analyses of tropopause folding, J. Geophys. Res., 82, 5867-5877, doi:10.1029/JC082i037p05867, 1977.

Davies, T. D. and Schuepbach, E.: Episodes of high ozone concentrations at the earth's surface resulting from transport down from the upper troposphere/lower stratosphere: a review and case studies, Atmos. Environ., 28, 53-68, doi:10.1016/13522310(94)90022-1, 1994.

Derwent, R. G., Simmonds, P. G., Manning, A. J., and Spain, T. G.: Trends over a 20-year period from 1987 to 2007 in surface ozone at the atmospheric research station, Mace Head, Ireland, Atmos. Environ., 41, 9091-9098, doi:10.1016/j.atmosenv.2007.08.008, 2007.

Draxler, R. R. and Rolph, G. D.: HYSPLIT (HYbrid Single-Particle Lagrangian Integrated Trajectory) model access via NOAA ARL READY website, NOAA Air Resources Laboratory, Silver Spring, Md, USA, available at: http://www.arl.noaa.gov/ready/ hysplit4.html (last access: 25 May 2016), 2003.

Draxler, R., Stunder, B., Rolph, G., and Taylor, A.: Hysplit 4 User's Guide, NOAA Air Resources Laboratory, Silver Spring, USA, 2009.

Dufour, G., Eremenko, M., Orphal, J., and Flaud, J.-M.: IASI observations of seasonal and day-to-day variations of tropospheric ozone over three highly populated areas of China: Beijing, Shanghai, and Hong Kong, Atmos. Chem. Phys., 10, $3787-$ 3801, doi:10.5194/acp-10-3787-2010, 2010.

Engström, A. and Magnusson, L.: Estimating trajectory uncertainties due to flow dependent errors in the atmospheric analysis, Atmos. Chem. Phys., 9, 8857-8867, doi:10.5194/acp-9-8857-2009, 2009.

Feister, U. and Warmbt, W.: Long-term measurements of surface ozone in the German Democratic Republic, J. Atmos. Chem., 5, 1-21, doi:10.1007/BF00192500, 1987.

Forster, P., Ramaswamy, V., Artaxo, P., Bernstsen, T., Betts, R., Fahey, D. W., Haywood, J., Lean, J., Lowe, D. W., Myhre, G., Nganga, J., Prinn, R., Raga, G., Schulz, M., and Van Dorland, 
R.: Changes in atmospheric constituents and in radiative forcing, chap. 2, Cambridge University Press, Cambridge, UK and New York, NY, USA, 2007.

Gallardo, L., Carrasco, J., and Olivares, G.: An analysis of ozone measurements at Cerro Tololo $\left(30^{\circ} \mathrm{S}, 70^{\circ} \mathrm{W}\right.$, 2200 m a.s.1.) in Chile, Tellus B, 52, 50-59, doi:10.1034/j.16000889.2000.00959.x, 2000.

Gao, J., Wang, T., Ding, A., and Liu, C.: Observational study of ozone and carbon monoxide at the summit of mount Tai (1534 m a.s.1.) in central-eastern China, Atmos. Environ., 39, 4779-4791, doi:10.1016/j.atmosenv.2005.04.030, 2005.

Granier, C., Bessagnet, B., Bond, T., D’Angiola, A., Denier van der Gon, H., Frost, G. J., Heil, A., Kaiser, J. W., Kinne, S., Klimont, Z., Kloster, S., Lamarque, J.-F., Liousse, C., Masui, T., Meleux, F., Mieville, A., Ohara, T., Raut, J.-C., Riahi, K., Schultz, M. G., Smith, S. J., Thompson, A., van Aardenne, J., van der Werf, G. R., and van Vuuren, D. P.: Evolution of anthropogenic and biomass burning emissions of air pollutants at global and regional scales during the 1980-2010 period, Clim. Change, 109, 163-190, doi:10.1007/s10584-011-0154-1, 2011.

Harris, J. M., Draxler, R. R., and Oltmans, S. J.: Trajectory model sensitivity to differences in input data and vertical transport method, J. Geophys. Res., 110, D14109, doi:10.1029/2004JD005750, 2005.

Huntzicker, J. J. and Johnson, R. L.: Investigation of an ambient interference in the measurement of ozone by ultraviolet absorption photometry, Environ. Sci. Technol., 13, 1414-1416, doi:10.1021/es60159a005, 1979.

IPCC: Summary for Policymakers, in: Climate Change 2013: The Physical Science Basis. Contribution of Working Group I to the Fifth Assessment Report of the Intergovernmental Panel on Climate Change, edited by: Stocker, T. F., Qin, D., Plattner, G.-K., Tignor, M., Allen, S. K., Boschung, J., Nauels, A., Xia, Y., Bex, V., and Midgley, P. M., Cambridge University Press, Cambridge, UK and New York, NY, USA, 2013.

Jacob, D. J., Logan, J. A., and Murti, P. P.: Effect of rising Asian emissions on surface ozone in the United States, Geophys. Res. Lett., 26, 2175-2178, doi:10.1029/1999GL900450, 1999.

Jaffe, D., Price, H., Parrish, D., Goldstein, A., and Harris, J.: Increasing background ozone during spring on the west coast of North America, Geophys. Res. Lett., 30, 1613, doi:10.1029/2003GL017024, 2003.

Jaffe, D., Bertschi, I., Jaeglé, L., Novelli, P., Reid, J. S., Tanimoto, H., Vingarzan, R., and Westphal, D. L.: Long-range transport of Siberian biomass burning emissions and impact on surface ozone in western North America, Geophys. Res. Lett., 31, L16106, doi:10.1029/2004GL020093, 2004.

Kalnay, E., Kanamitsu, M., Kistler, R., Collins, W., Deaven, D., Gandin, L., Iredell, M., Saha, S., White, G., Woollen, J., and Zhu, Y.: The NCEP/NCAR 40-year reanalysis project, B. Am. Meteorol. Soc., 77, 437-471, 1996.

Komhyr, W. D.: Electrochemical concentration cells for gas analysis, Ann. Geophys., 25, 203-210, 1969.

Ladstätter-Weißenmayer, A., Meyer-Arnek, J., Schlemm, A., and Burrows, J. P.: Influence of stratospheric airmasses on tropospheric vertical $\mathrm{O}_{3}$ columns based on GOME (Global Ozone Monitoring Experiment) measurements and backtrajectory calculation over the Pacific, Atmos. Chem. Phys., 4, 903-909, doi:10.5194/acp-4-903-2004, 2004.
Langford, A. O., Brioude, J., Cooper, O. R., Senff, C. J., Alvarez, R. J., Hardesty, R. M., Johnson, B. J., and Oltmans, S. J.: Stratospheric influence on surface ozone in the Los Angeles area during late spring and early summer of 2010, J. Geophys. Res., 117, D00V06, doi:10.1029/2011JD016766, 2012.

Langford, A. O., Pierce, R. B., and Schultz, P. J.: Stratospheric intrusions, the Santa Ana winds, and wildland fires in Southern California, Geophys. Res. Lett., 42, 6091-6097, doi:10.1002/2015GL064964, 2015.

Law, K. S., Plantevin, P.-H., Thouret, V., Marenco, A., Asman, W. A. H., Lawrence, M., Crutzen, P. J., Muller, J.-F., Hauglustaine, D. A., and Kanakidou, M.: Comparison between global chemistry transport model results and Measurement of Ozone and Water Vapor by Airbus In-Service Aircraft (MOZAIC) data, J. Geophys. Res., 105, 1503, doi:10.1029/1999JD900474, 2000.

Leblanc, T.: TMO lidar data at NDACC database, available at: ftp:// ftp.cpc.ncep.noaa.gov/ndacc/station/tmo/ames/lidar/, last access: 25 July 2016.

Leblanc, T., McDermid, I. S., and Walsh, T. D.: Ground-based water vapor raman lidar measurements up to the upper troposphere and lower stratosphere for long-term monitoring, Atmos. Meas. Tech., 5, 17-36, doi:10.5194/amt-5-17-2012, 2012.

Lee, S., Akimoto, H., Nakane, H., Kurnosenko, S., and Kinjo, Y.: Lower tropospheric ozone trend observed in 1989-1997 at Okinawa, Japan, Geophys. Res. Lett., 25, 1637-1640, doi:10.1029/98GL01224, 1998.

Lefohn, A. S., Wernli, H., Shadwick, D., Limbach, S., Oltmans, S. J., and Shapiro, M.: The importance of stratospherictropospheric transport in affecting surface ozone concentrations in the western and northern tier of the United States, Atmos. Environ., 45, 4845-4857, doi:10.1016/j.atmosenv.2011.06.014, 2011.

Lefohn, A. S., Wernli, H., Shadwick, D., Oltmans, S. J., and Shapiro, M.: Quantifying the importance of stratospherictropospheric transport on surface ozone concentrations at highand low-elevation monitoring sites in the United States, Atmos. Environ., 62, 646-656, doi:10.1016/j.atmosenv.2012.09.004, 2012.

Lelieveld, J., van Aardenne, J., Fischer, H., de Reus, M., Williams, J., and Winkler, P.: Increasing ozone over the Atlantic Ocean, Science, 304, 1483-1487, doi:10.1126/science.1096777, 2004.

Levy, H., Mahlman, J. D., Moxim, W. J., and Liu, S. C.: Tropospheric ozone: The role of transport, J. Geophys. Res., 90, 3753, doi:10.1029/JD090iD02p03753, 1985.

Liang, Q., Jaeglé, L., Jaffe, D. A., Weiss-Penzias, P., Heckman, A., and Snow, J. A.: Long-range transport of Asian pollution to the northeast Pacific: Seasonal variations and transport pathways of carbon monoxide, J. Geophys. Res., 109, D23S07, doi:10.1029/2003JD004402, 2004.

Lin, M., Fiore, A. M., Cooper, O. R., Horowitz, L. W., Langford, A. O., Levy, H., Johnson, B. J., Naik, V., Oltmans, S. J., and Senff, C. J.: Springtime high surface ozone events over the western United States: Quantifying the role of stratospheric intrusions, J. Geophys. Res., 117, D00V22, doi:10.1029/2012JD018151, 2012a.

Lin, M., Fiore, A. M., Horowitz, L. W., Cooper, O. R., Naik, V., Holloway, J., Johnson, B. J., Middlebrook, A. M., Oltmans, S. J., Pollack, I. B., Ryerson, T. B., Warner, J. X., Wiedinmyer, C., Wilson, J., and Wyman, B.: Transport of Asian ozone pollution 
into surface air over the western United States in spring, J. Geophys. Res., 117, D00V07, doi:10.1029/2011JD016961, 2012 b.

Lin, M., Horowitz, L. W., Oltmans, S. J., Fiore, A. M., and Fan, S.: Tropospheric ozone trends at Mauna Loa Observatory tied to decadal climate variability, Nat. Geosci., 7, 136-143, doi:10.1038/NGEO2066, 2014.

Lin, M., Fiore, A. M., Horowitz, L. W., Langford, A. O., Oltmans, S. J., Tarasick, D., and Rieder, H. E.: Climate variability modulates western US ozone air quality in spring via deep stratospheric intrusions, Nat. Commun., 6, 7105, doi:10.1038/ncomms8105, 2015a.

Lin, M., Horowitz, L. W., Cooper, O. R., Tarasick, D., Conley, S., Iraci, L. T., Johnson, B., Leblanc, T., Petropavlovskikh, I., and Yates, E. L.: Revisiting the evidence of increasing springtime ozone mixing ratios in the free troposphere over western North America, Geophys. Res. Lett., 42, 8719-8728, doi:10.1002/2015GL065311, 2015b.

Logan, J. A.: Trends in the vertical distribution of ozone: An analysis of ozonesonde data, J. Geophys. Res., 99, 25553, doi:10.1029/94JD02333, 1994.

Logan, J. A., Megretskaia, I. A., Miller, A. J., Tiao, G. C., Choi, D., Zhang, L., Stolarski, R. S., Labow, G. J., Hollandsworth, S. M., Bodeker, G. E., Claude, H., De Muer, D., Kerr, J. B., Tarasick, D. W., Oltmans, S. J., Johnson, B., Schmidlin, F., Staehelin, J., Viatte, P., and Uchino, O.: Trends in the vertical distribution of ozone: A comparison of two analyses of ozonesonde data, J. Geophys. Res., 104, 26373, doi:10.1029/1999JD900300, 1999.

Logan, J. A., Staehelin, J., Megretskaia, I. A., Cammas, J.-P., Thouret, V., Claude, H., De Backer, H., Steinbacher, M., Scheel, H. E., Stübi, R., Fröhlich, M., and Derwent, R.: Changes in ozone over Europe since 1990: analysis of ozone measurements from sondes, regular aircraft (MOZAIC) and alpine surface sites, J. Geophys. Res., 117, D09301, doi:10.1029/2011JD016952, 2012.

McDermid, I. S.: Differential absorption lidar systems for tropospheric and stratospheric ozone measurements, Opt. Eng., 30, 22-30, doi:10.1117/12.55768, 1991.

McDermid, S., Beyerle, G., Haner, D. A., and Leblanc, T.: Redesign and improved performance of the tropospheric ozone lidar at the Jet Propulsion Laboratory Table Mountain Facility, Appl. Optics, 41, 7550-7555, 2002.

Mickley, L. J., Jacob, D. J., and Rind, D.: Uncertainty in preindustrial abundance of tropospheric ozone: Implications for radiative forcing calculations, J. Geophys. Res., 106, 3389, doi:10.1029/2000JD900594, 2001.

Monks, P.: Gas-phase radical chemistry in the troposphere, Chem. Soc. Rev., 34, 376-395, doi:10.1039/B307982C, 2005.

Naja, M. and Akimoto, H.: Contribution of regional pollution and long-range transport to the Asia-Pacific region: Analysis of long-term ozonesonde data over Japan, J. Geophys. Res., 109, D21306, doi:10.1029/2004JD004687, 2004.

Naja, M., Lal, S., and Chand, D.: Diurnal and seasonal variabilities in surface ozone at a high altitude site Mt. Abu $\left(24.6^{\circ} \mathrm{N}\right.$, $72.7^{\circ} \mathrm{E}, 1680 \mathrm{~m}$ a.s.1.) in India, Atmos. Environ., 37, 4205-4215, doi:10.1016/S1352-2310(03)00565-X, 2003.

Neu, J. L., Flury, T., Manney, G. L., Santee, M. L., Livesey, N. J., and Worden, J.: Tropospheric ozone variations governed by changes in stratospheric circulation, Nat. Geosci., 7, 340-344, doi:10.1038/ngeo2138, 2014.
Neuman, J. A., Trainer, M., Aikin, K. C., Angevine, W. M., Brioude, J., Brown, S. S., de Gouw, J. A., Dube, W. P., Flynn, J. H., Graus, M., Holloway, J. S., Lefer, B. L., Nedelec, P., Nowak, J. B., Parrish, D. D., Pollack, I. B., Roberts, J. M., Ryerson, T. B., Smit, H., Thouret, V., and Wagner, N. L.: Observations of ozone transport from the free troposphere to the Los Angeles basin, J. Geophys. Res., 117, D00V09, doi:10.1029/2011JD016919, 2012.

Newchurch, M. J., Ayoub, M. A., Oltmans, S., Johnson, B., and Schmidlin, F. J.: Vertical distribution of ozone at four sites in the United States, J. Geophys. Res., 108, 4031, doi:10.1029/2002JD002059, 2003.

Oltmans, S. J. and Komhyr, W. D.: Surface ozone distributions and variations from 1973-1984: Measurements at the NOAA Geophysical Monitoring for Climatic Change Baseline Observatories, J. Geophys. Res., 91, 5229, doi:10.1029/JD091iD04p05229, 1986.

Oltmans, S. J., Lefohn, A. S., Scheel, H. E., Harris, J. M., Levy, H., Galbally, I. E., Brunke, E.-G., Meyer, C. P., Lathrop, J. A., Johnson, B. J., Shadwick, D. S., Cuevas, E., Schmidlin, F. J., Tarasick, D. W., Claude, H., Kerr, J. B., Uchino, O., and Mohnen, V.: Trends of ozone in the troposphere, Geophys. Res. Lett., 25, 139-142, doi:10.1029/97GL03505, 1998.

Oltmans, S. J., Lefohn, A. S., Harris, J. M., Galbally, I., Scheel, H. E., Bodeker, G., Brunke, E., Claude, H., Tarasick, D., Johnson, B. J., Simmonds, P., Shadwick, D., Anlauf, K., Hayden, K., Schmidlin, F., Fujimoto, T., Akagi, K., Meyer, C., Nichol, S., Davies, J., Redondas, A., and Cuevas, E.: Long-term changes in tropospheric ozone, Atmos. Environ., 40, 3156-3173, doi:10.1016/j.atmosenv.2006.01.029, 2006.

Oltmans, S. J., Lefohn, a. S., Shadwick, D., Harris, J. M., Scheel, H. E., Galbally, I., Tarasick, D. W., Johnson, B. J., Brunke, E. G., Claude, H., Zeng, G., Nichol, S., Schmidlin, F., Davies, J., Cuevas, E., Redondas, A., Naoe, H., Nakano, T., and Kawasato, T.: Recent tropospheric ozone changes - A pattern dominated by slow or no growth, Atmos. Environ., 67, 331-351, doi:10.1016/j.atmosenv.2012.10.057, 2013.

Parrish, D., Dunlea, E. J., Atlas, E. L., Schauffler, S., Donnelly, S., Stroud, V., Goldstein, A. H., Millet, D. B., McKay, M., Jaffe, D. A., Price, H. U., Hess, P. G., Flocke, F., and Roberts, J. M.: Changes in the photochemical environment of the temperate North Pacific troposphere in response to increased Asian emissions, J. Geophys. Res., 109, D23S18, doi:10.1029/2004JD004978, 2004.

Parrish, D. D., Millet, D. B., and Goldstein, A. H.: Increasing ozone in marine boundary layer inflow at the west coasts of North America and Europe, Atmos. Chem. Phys., 9, 1303-1323, doi:10.5194/acp-9-1303-2009, 2009.

Parrish, D. D., Law, K. S., Staehelin, J., Derwent, R., Cooper, O. R., Tanimoto, H., Volz-Thomas, A., Gilge, S., Scheel, H.-E., Steinbacher, M., and Chan, E.: Long-term changes in lower tropospheric baseline ozone concentrations at northern mid-latitudes, Atmos. Chem. Phys., 12, 11485-11504, doi:10.5194/acp-1211485-2012, 2012.

Petetin, H., Thouret, V., Fontaine, A., Sauvage, B., Athier, G., Blot, R., Boulanger, D., Cousin, J.-M., and Nedelec, P.: Characterizing tropospheric ozone and CO around Frankfurt between 1994 2012 based on MOZAIC-IAGOS aircraft measurements, Atmos. Chem. Phys. Discuss., 15, 23841-23891, doi:10.5194/acpd-1523841-2015, 2015. 
Pochanart, P., Hirokawa, J., and Kajii, Y.: Influence of regionalscale anthropogenic activity in northeast Asia on seasonal variations of surface ozone and carbon monoxide observed at Oki, Japan, J. Geophys. Res., 104, 3621-3631, 1999.

Proffitt, M. H. and Langford, A. O.: Ground-based differential absorption lidar system for day or night measurements of ozone throughout the free troposphere, Appl. Optics, 36, 2568-2585, 1997.

Randel, W. J., Seidel, D. J., and Pan, L. L.: Observational characteristics of double tropopauses, J. Geophys. Res., 112, D07309, doi:10.1029/2006JD007904, 2007.

Rao, T. N., Kirkwood, S., Arvelius, J., von der Gathen, P., and Kivi, R.: Climatology of UTLS ozone and the ratio of ozone and potential vorticity over northern Europe, J. Geophys. Res., 108, 4703, doi:10.1029/2003JD003860, 2003.

Reidmiller, D. R., Fiore, A. M., Jaffe, D. A., Bergmann, D., Cuvelier, C., Dentener, F. J., Duncan, B. N., Folberth, G., Gauss, M., Gong, S., Hess, P., Jonson, J. E., Keating, T., Lupu, A., Marmer, E., Park, R., Schultz, M. G., Shindell, D. T., Szopa, S., Vivanco, M. G., Wild, O., and Zuber, A.: The influence of foreign vs. North American emissions on surface ozone in the US, Atmos. Chem. Phys., 9, 5027-5042, doi:10.5194/acp-9-5027-2009, 2009.

Rienecker, M. M., Suarez, M. J., Gelaro, R., Todling, R., Bacmeister, J., Liu, E., Bosilovich, M. G., Schubert, S. D., Takacs, L., Kim, G.-K., Bloom, S., Chen, J., Collins, D., Conaty, A., da Silva, A., Gu, W., Joiner, J., Koster, R. D., Lucchesi, R., Molod, A., Owens, T., Pawson, S., Pegion, P., Redder, C. R., Reichle, R., Robertson, F. R., Ruddick, A. G., Sienkiewicz, M., and Woolen, J.: MERRA: NASA's Modern-Era Retrospective Analysis for Research and Applications, J. Climate, 24, 3624-3648, doi:10.1175/JCLI-D-11-00015.1, 2011.

Roelofs, G.-J. and Lelieveld, J.: Model study of the influence of cross-tropopause $\mathrm{O}_{3}$ transports on tropospheric $\mathrm{O}_{3}$ levels, Tellus B, 49, 38-55, doi:10.1034/j.1600-0889.49.issue1.3.x, 1997.

The Royal Society: Ground-level ozone in the 21st century: future trends, impacts and policy implications, Science Policy Report 15/08, London, UK, 2008.

Schnell, J. L., Prather, M. J., Josse, B., Naik, V., Horowitz, L. W., Cameron-Smith, P., Bergmann, D., Zeng, G., Plummer, D. A., Sudo, K., Nagashima, T., Shindell, D. T., Faluvegi, G., and Strode, S. A.: Use of North American and European air quality networks to evaluate global chemistry-climate modeling of surface ozone, Atmos. Chem. Phys., 15, 10581-10596, doi:10.5194/acp-15-10581-2015, 2015.

Simmonds, P. G., Derwent, R. G., Manning, A. L., and Spain, G.: Significant growth in surface ozone at Mace Head, Ireland, 1987-2003, Atmos. Environ., 38, 4769-4778, doi:10.1016/j.atmosenv.2004.04.036, 2004.

Sinha, V., Kumar, V., and Sarkar, C.: Chemical composition of premonsoon air in the Indo-Gangetic Plain measured using a new air quality facility and PTR-MS: high surface ozone and strong influence of biomass burning, Atmos. Chem. Phys., 14, 59215941, doi:10.5194/acp-14-5921-2014, 2014.

Smit, H. G. J., Straeter, W., Johnson, B. J., Oltmans, S. J., Davies, J., Tarasick, D. W., Hoegger, B., Stubi, R., Schmidlin, F. J., Northam, T., Thompson, A. M., Witte, J. C., Boyd, I., and Posny, F.: Assessment of the performance of ECC-ozonesondes under quasi-flight conditions in the environmental simulation chamber: Insights from the Juelich Ozone Sonde Intercomparison Experiment (JOSIE), J. Geophys. Res., 112, D19306, doi:10.1029/2006JD007308, 2007.

Sprenger, M.: A northern hemispheric climatology of crosstropopause exchange for the ERA15 time period (1979-1993), J. Geophys. Res., 108, 8521, doi:10.1029/2002JD002636, 2003.

Staehelin, J., Thudium, J., Buehler, R., Volz-Thomas, A., and Graber, W.: Trends in surface ozone concentrations at Arosa (Switzerland), Atmos. Environ., 28, 75-87, doi:10.1016/13522310(94)90024-8, 1994.

Stevenson, D. S., Dentener, F. J., Schultz, M. G., Ellingsen, K., van Noije, T. P. C., Wild, O., Zeng, G., Amann, M., Atherton, C. S., Bell, N., Bergmann, D. J., Bey, I., Butler, T., Cofala, J., Collins, W. J., Derwent, R. G., Doherty, R. M., Drevet, J., Eskes, H. J., Fiore, A. M., Gauss, M., Hauglustaine, D. A., Horowitz, L. W., Isaksen, I. S. A., Krol, M. C., Lamarque, J.-F., Lawrence, M. G., Montanaro, V., Müller, J.-F., Pitari, G., Prather, M. J., Pyle, J. A., Rast, S., Rodriguez, J. M., Sanderson, M. G., Savage, N. H., Shindell, D. T., Strahan, S. E., Sudo, K., and Szopa, S.: Multimodel ensemble simulations of present-day and near-future tropospheric ozone, J. Geophys. Res., 111, D08301, doi:10.1029/2005JD006338, 2006.

Stohl, A.: On the pathways and timescales of intercontinental air pollution transport, J. Geophys. Res., 107, 4684, doi:10.1029/2001JD001396, 2002.

Stohl, A.: Stratosphere-troposphere exchange: A review, and what we have learned from STACCATO, J. Geophys. Res., 108, 8516, doi:10.1029/2002JD002490, 2003.

Stohl, A. and Seibert, P.: Accuracy of trajectories as determined from the conservation of meteorological tracers, Q. J. Roy. Meteor. Soc., 124, 1465-1484, doi:10.1002/qj.49712454907, 1998.

Strode, S. A., Rodriguez, J. M., Logan, J. A., Cooper, O. R., Witte, J. C., Lamsal, L. N., Damon, M., Van Aartsen, B., Steenrod, S. D., and Strahan, S. E.: Trends and variability in surface ozone over the United States, J. Geophys. Res., 120, 9020-9042, doi:10.1002/2014JD022784, 2015.

Tanimoto, H., Ohara, T., and Uno, I.: Asian anthropogenic emissions and decadal trends in springtime tropospheric ozone over Japan: 1998-2007, Geophys. Res. Lett., 36, L23802, doi:10.1029/2009GL041382, 2009.

Thompson, A. M., Stone, J. B., Witte, J. C., Miller, S. K., Oltmans, S. J., Kucsera, T. L., Ross, K. L., Pickering, K. E., Merrill, J. T., Forbes, G., Tarasick, D. W., Joseph, E., Schmidlin, F. J., McMillan, W. W., Warner, J., Hintsa, E. J., and Johnson, J. E.: Intercontinental Chemical Transport Experiment Ozonesonde Network Study (IONS) 2004: 2. Tropospheric ozone budgets and variability over northeastern North America, J. Geophys. Res., 112, D12S13, doi:10.1029/2006JD007670, 2007.

Tie, X., Geng, F., Peng, L., Gao, W., and Zhao, C.: Measurement and modeling of $\mathrm{O}_{3}$ variability in Shanghai, China: Application of the WRF-Chem model, Atmos. Environ., 43, 4289-4302, doi:10.1016/j.atmosenv.2009.06.008, 2009.

Trickl, T., Feldmann, H., Kanter, H.-J., Scheel, H.-E., Sprenger, M., Stohl, A., and Wernli, H.: Forecasted deep stratospheric intrusions over Central Europe: case studies and climatologies, Atmos. Chem. Phys., 10, 499-524, doi:10.5194/acp-10-499-2010, 2010.

Trickl, T., Bärtsch-Ritter, N., Eisele, H., Furger, M., Mücke, R., Sprenger, M., and Stohl, A.: High-ozone layers in the middle and 
upper troposphere above Central Europe: potential import from the stratosphere along the subtropical jet stream, Atmos. Chem. Phys., 11, 9343-9366, doi:10.5194/acp-11-9343-2011, 2011.

Tsutsumi, Y. and Matsueda, H.: Relationship of ozone and CO at the summit of Mt. Fuji $\left(35.35^{\circ} \mathrm{N}, 138.73^{\circ} \mathrm{E}, 3776 \mathrm{~m}\right.$ above sea level) in summer 1997, Atmos. Environ., 34, 553-561, doi:10.1016/S1352-2310(99)00238-1, 2000.

Vaughan, G., Price, J. D., and Howells, A.: Transport into the troposphere in a tropopause fold, Q. J. Roy. Meteor. Soc., 120, 10851103, doi:10.1002/qj.49712051814, 1994.

Verstraeten, W. W., Neu, J. L., Williams, J. E., Bowman, K. W., Worden, J. R., and Boersma, K. F.: Rapid increases in tropospheric ozone production and export from China, Nat. Geosci., 8, 690-695, doi:10.1038/NGEO2493, 2015.

Volz, A. and Kley, D.: Evaluation of the Montsouris series of ozone measurements made in the nineteenth century, Nature, 332, 240242, doi:10.1038/332240a0, 1988.

Wang, T., Ding, A., Gao, J., and Wu, W. S.: Strong ozone production in urban plumes from Beijing, China, Geophys. Res. Lett., 33, L21806, doi:10.1029/2006GL027689, 2006.

WMO (World Meteorological Organization): A three-dimensional science: Second session of the commission for aerology, WMO Bull., IV, Geneva, Switzerland, 1957.

World Health Organization: Health aspects of air pollution with particulate matter, ozone and nitrogen dioxide: report on a WHO working group, 13-15 January 2003, Bonn, Germany, 2003.

Yates, E. L., Iraci, L. T., Roby, M. C., Pierce, R. B., Johnson, M. S., Reddy, P. J., Tadić, J. M., Loewenstein, M., and Gore, W.: Airborne observations and modeling of springtime stratosphereto-troposphere transport over California, Atmos. Chem. Phys., 13, 12481-12494, doi:10.5194/acp-13-12481-2013, 2013.

Young, P. J., Archibald, A. T., Bowman, K. W., Lamarque, J.-F., Naik, V., Stevenson, D. S., Tilmes, S., Voulgarakis, A., Wild, O., Bergmann, D., Cameron-Smith, P., Cionni, I., Collins, W. J., Dalsøren, S. B., Doherty, R. M., Eyring, V., Faluvegi, G., Horowitz, L. W., Josse, B., Lee, Y. H., MacKenzie, I. A., Nagashima, T., Plummer, D. A., Righi, M., Rumbold, S. T., Skeie, R. B., Shindell, D. T., Strode, S. A., Sudo, K., Szopa, S., and Zeng, G.: Preindustrial to end 21st century projections of tropospheric ozone from the Atmospheric Chemistry and Climate Model Intercomparison Project (ACCMIP), Atmos. Chem. Phys., 13, 2063 2090, doi:10.5194/acp-13-2063-2013, 2013.
Zbinden, R. M., Cammas, J.-P., Thouret, V., Nédélec, P., Karcher, F., and Simon, P.: Mid-latitude tropospheric ozone columns from the MOZAIC program: climatology and interannual variability, Atmos. Chem. Phys., 6, 1053-1073, doi:10.5194/acp-6-1053-2006, 2006.

Zbinden, R. M., Thouret, V., Ricaud, P., Carminati, F., Cammas, J.P., and Nédélec, P.: Climatology of pure tropospheric profiles and column contents of ozone and carbon monoxide using MOZAIC in the mid-northern latitudes $\left(24^{\circ} \mathrm{N}\right.$ to $\left.50^{\circ} \mathrm{N}\right)$ from 1994 to 2009, Atmos. Chem. Phys., 13, 12363-12388, doi:10.5194/acp13-12363-2013, 2013.

Zhang, L., Jacob, D. J., Boersma, K. F., Jaffe, D. A., Olson, J. R., Bowman, K. W., Worden, J. R., Thompson, A. M., Avery, M. A., Cohen, R. C., Dibb, J. E., Flock, F. M., Fuelberg, H. E., Huey, L. G., McMillan, W. W., Singh, H. B., and Weinheimer, A. J.: Transpacific transport of ozone pollution and the effect of recent Asian emission increases on air quality in North America: an integrated analysis using satellite, aircraft, ozonesonde, and surface observations, Atmos. Chem. Phys., 8, 6117-6136, doi:10.5194/acp-8-6117-2008, 2008.

Zhang, L., Jacob, D. J., Liu, X., Logan, J. A., Chance, K., Eldering, A., and Bojkov, B. R.: Intercomparison methods for satellite measurements of atmospheric composition: application to tropospheric ozone from TES and OMI, Atmos. Chem. Phys., 10, 4725-4739, doi:10.5194/acp-10-4725-2010, 2010. 